\title{
APROXIMACIÓN AL DELITO DE COHECHO
}

I. Introducción; II. Concepto; III. Clasificación; IV. Naturaleza unilateral o bilateral; V. Bien jurídico; VI Figura básica de cobecho del funcionario público, activo o pasivo (art. 248); VII. Primera figura agravada de cohecho del funcionario público, activo o pasivo (art. 248 bis); VIII. Segunda figura agravada de cohecho del funcionario público, activo o pasivo (art. 249); IX. Figura básica de cohecho del particular, activo o pasivo (art. 250); X. Figura privilegiada de cohecho del particular. Cohecho en causa criminal a favor del procesado (art. 250 bis); XI. Acerca del iter criminis en los diversos tipos de cohecho, tanto del funcionario, como del particular; XII. Bibliografía.

\section{Introducción}

Pocas veces se ha escuchado hablar tanto del fenómeno de la corrupción como en el último tiempo. Algunos procesos penales recientes seguidos en contra de conocidos funcionarios públicos han convertido este problema en importante objeto de preocupación de la comunidad nacional. La corrupción en el ámbito de las funciones públicas presenta un alto grado de impacto, no sólo porque conduce a una frustración de las expectativas de los ciudadanos, quienes esperan que los funcionarios públicos se desempeñen con probidad en el ejercicio de sus cargos, sino también porque posee una gran capacidad para socavar las bases del sistema político imperante ${ }^{2}$. Sin embargo, no debe creerse que se trata de un fenómeno presente sólo en el ámbito público. También en el sector privado existe corrupción, atendido el hecho de que ésta conduce a infringir deberes que pueden tener su fuente, tanto en disposiciones legales, como contractuales ${ }^{3}$. Con todo, no es difícil constatar que la corrupción en el ámbito privado no provoca tanta alarma como en el sector público. Es quizás esa la razón por la cual el legislador se ha preocupado más de la corrupción en el ámbito público. ${ }^{4}$

\footnotetext{
${ }^{1}$ El presente trabajo ha sido realizado en el marco del Proyecto de Investigación Fondecyt $\mathrm{N}^{\circ} 1020657$, "Protección penal de la fe pública y de las funciones estatales: estudio dogmático y crítico", bajo la dirección del Profesor de Derecho Penal de la Pontificia Universidad Católica de Valparaíso, Dr. Sr. Luis Rodríguez Collao.

* Profesor de Derecho Penal, Pontificia Universidad Católica de Valparaíso

2 En este sentido, cfr. OSSANDÓN WIDOW, Consideraciones politico-criminales sobre el delito de tráfico de influencias, en Revista de Derecho de la Universidad Católica del Norte No 10, año 2003, p. 161.

${ }^{3}$ Cfr. SABán Godoy, El marco jurídico de la corrupción, Ed. Civitas, Madrid, 1991, p. 15: "Esto nos llevaría sin más a una conclusión incontestable que, sin embargo, en pocas ocasiones se liga al concepto de corrupción. Nos referimos a su existencia en el ámbito privado. El empleado que monta negocios paralelos a aquéllos en que trabaja por cuenta ajena, desviando así la potencial clientela de éste, es un empleado corrupto. Igual sucede con quien facilita información a la competencia y obtiene por ello un beneficio personal. Ya desde este momento podemos afirmar que las causas de corrupción son las mismas y que la cuantía de los casos no tiene por qué ser sustancialmente distinta. Téngase, además, en cuenta que tras todos los casos de corrupción pública existe una complicidad privada. Como tendremos ocasión de afirmar, lo corrupto es un entorno social sin distinción alguna entre lo público y lo privado". Sobre el fenómeno de la corrupción en el sector privado puede verse también Ferreira Delgado, Delitos contra la Administración Pública, $2^{\mathrm{a}}$ edición, Ed. Temis, Bogotá, 1985, pp. 79 a 81.

${ }^{4}$ Sobre el tema global de la corrupción puede verse BALLÉn, Corrupción politica, Ed. Acrópolis - Ed. Jurídica Gustavo Ibáñez, Bogotá, 1994.
} 
Oliver - Aproximación al delito de cohecho

Esta especial preocupación por la corrupción en el sector público se tradujo en la dictación de la ley $\mathrm{N}^{\mathrm{o}}$ 19.645, publicada en el Diario Oficial del 11 de diciembre de 1999, que, básicamente, introdujo una serie de modificaciones en el título $\mathrm{V}$ del libro II del Código Penal. La propia denominación con que esta ley fue publicada ("Ley num. 19.645. Modifica disposiciones del Código Penal que sancionan delitos de corrupción") demuestra que para el legislador el problema de la corrupción se centra en el ámbito público, dado que sólo se hicieron cambios en la regulación de los delitos cometidos por empleados públicos. Además, esta ley tuvo como importante antecedente la Convención interamericana contra la corrupción, adoptada en Caracas el 29 de marzo de 1996, aprobada por el Congreso Nacional en septiembre de 1998 y promulgada mediante Decreto Supremo del Ministerio de Relaciones Exteriores No 1879, del 29 de octubre de 1998, que se publicó en el Diario Oficial de fecha 2 de febrero de 1999. En el artículo VI de la Convención se mencionan los actos de corrupción a los cuales les será aplicable aquélla, los que presentan la particularidad de ser realizados por funcionarios públicos, circunstancia que viene a confirmar la señalada tesis ${ }^{5}$.

Dentro del complejo fenómeno de la corrupción en el sector público, el delito de cohecho aparece como una de sus manifestaciones más importantes. En efecto, cuando se habla de la corrupción, tradicionalmente, se piensa en el cohecho como uno de los delitos más paradigmáticos, junto con el tráfico de influencias ${ }^{6}$. Tanto es así que, incluso, en el Código Penal español de 1995, la única disposición que alude a la idea de corrupción salvo la que se refiere a la corrupción de menores e incapaces- es el art. 423.1, que, precisamente, tipifica una figura de cohecho ${ }^{7}$.

5 Art. VI de la Convención Interamericana contra la corrupción: “Articulo VI. Actos de Corrupción. 1. La presente Convención es aplicable a los siguientes actos de corrupción: a. El requerimiento o la aceptación, directa o indirectamente, por un funcionario público o una persona que ejerza funciones públicas, de cualquier objeto de valor pecuniario $u$ otros beneficios como dádivas, favores, promesas o ventajas para si mismo o para otra persona o entidad a cambio de la realización u omisión de cualquier acto en el ejercicio de sus funciones públicas;

b. El ofrecimiento o el otorgamiento, directa o indirectamente, a un funcionario público o a una persona que ejerza funciones públicas, de cualquier objeto de valor pecuniario u otros beneficios como dádivas, favores, promesas o ventajas para ese funcionario público o para otra persona o entidad a cambio de la realización $u$ omisión de cualquier acto en el ejercicio de sus funciones públicas;

c. La realización por parte de un funcionario público o una persona que ejerza funciones públicas de cualquier acto $u$ omisión en el ejercicio de sus funciones, con el fin de obtener ilicitamente beneficios para sí mismo o para un tercero;

d. El aprovechamiento doloso u ocultación de bienes provenientes de cualesquiera de los actos a los que se refiere el presente articulo; $y$

e. La participación como autor, coautor, instigador, cómplice, encubridor o en cualquier otra forma en la comisión, tentativa de comisión, asociación o confabulación para la comisión de cualquiera de los actos a los que se refiere el presente artículo.

2. La presente Convención también será aplicable, de mutuo acuerdo entre dos o más Estados Partes, en relación con cualquier otro acto de corrupción no contemplado en ella."

6 Cfr. Buompadre, Delitos contra la Administración Pública. Doctrina y Jurisprudencia, Ed. Mave, Buenos Aires, 2001, p. 179: "Los delitos de cohecho y tráfico de influencias, en sus diversas manifestaciones, se han convertido en el paradigma penal, dentro del amplio espectro que comprende la problemática de la corrupción instalada en la función pública". En el mismo sentido, DíAZ y GARCía ConLLEDo, El delito de cohecho, en VV.AA., Delitos contra la Administración Pública, edición al cuidado de Adela Asúa Batarrita, Instituto Vasco de Administración Pública, Bilbao, 1997, p. 161.

7 Cfr. Octavio de Toledo y Ubieto, Derecho Penal, poderes públicos y negocios (con especial referencia a los delitos de cohecho), en VV.AA., El nuevo Código Penal: propósitos y fundamentos, Libro Homenaje al profesor Dr. Ángel Torío López, Ed. Comares, Granada, 1999, p. 868. 
La finalidad de este breve trabajo es efectuar algunas consideraciones acerca del delito de cohecho, a partir de la regulación establecida con la mencionada ley $\mathrm{N}^{\mathrm{o}} 19.645$, considerando también las modificaciones introducidas con la ley $\mathrm{N}^{\circ} 19.829$, publicada en el Diario Oficial del 8 de octubre de $2002^{8}$, y tomando en cuenta opiniones de la doctrina nacional y extranjera, especialmente la española.

\section{Concepto}

Para elaborar cualquier concepto suele resultar útil analizar el origen etimológico de las palabras. Sin embargo, en el caso del cohecho el uso de esta herramienta plantea de inmediato una dificultad, porque los autores no están de acuerdo en la determinación de la raíz etimológica del término "cohecho". En efecto, mientras por un lado, hay quienes creen que deriva de la voz latina conficere (en latín vulgar confectare y en castellano antiguo siglo XIII- confeitar), equivalente a sobornar o corromper a un funcionario público ${ }^{9}$, por otro, hay quienes piensan que procede del vocablo latino coactare, es decir, forzar, obligar, compeler, lo que obedecería a que, en un principio, el hecho realizado pudo revestir la idea de fuerza ${ }^{10}$. Esta falta de consenso en la doctrina obliga a desechar el recurso etimológico, al momento de intentar elaborar un concepto de cohecho.

En cualquier caso, prescindiendo de consideraciones etimológicas, es posible constatar en la doctrina algunos conceptos de cohecho que se han propuesto. Es el caso, por ejemplo, de Francesco Carrara, quien afirmaba, en una ya clásica definición, que el cohecho consiste en la "venta que de un acto perteneciente a sus funciones, y que por regla general debería ser gratuito, le hace un funcionario público a una persona privada" 11 . Desde ya debemos señalar que esta definición no resulta aplicable a nuestra regulación del cohecho, por las siguientes razones. En primer lugar, porque pone el acento en sólo uno de los sujetos intervinientes -el funcionario-, desconociendo que también puede haber cohecho únicamente con actividad del otro - el particular-. En segundo término, porque para que haya cohecho no es necesario que el funcionario reciba prestación alguna. $\mathrm{Y}$ en

\footnotetext{
Art. 423.1 del Código Penal español: "Los que con dádivas, presentes, ofrecimientos o promesas corrompieren o intentaren corromper a las autoridades o funcionarios públicos serán castigados con las mismas penas de prisión y multa que éstos".

${ }^{8}$ Esta última ley introdujo importantes cambios en esta materia. Por un lado, agregó dos nuevos artículos al Código Penal, el 250 bis A y el 250 bis B, con el fin de cumplir la obligación contraída por el país como adherente de la Convención para combatir el cohecho a funcionarios públicos extranjeros en transacciones comerciales internacionales y tipificar un nuevo delito de soborno transnacional. Por otro, modificó la regulación del cohecho del particular. En el presente trabajo no analizaremos el soborno transnacional. Para su estudio puede verse OLIVER CALDERÓN, Últimas modificaciones en la regulación del delito de cohecho (ley $N^{\circ} 19.829$ ), en Revista Chilena de Derecho, volumen $30 \mathrm{~N}^{\circ}$ 1, año 2003, Sección Estudios, pp. 39 y ss..

9 Así, Rodríguez Ramos, Transfuguismo retribuido y cohecho, en Actualidad Penal 1994-1, p. 441; CATALÁN SENDER, Los delitos cometidos por autoridades y funcionarios públicos en el nuevo Código Penal (doctrina y jurisprudencia), Ed. Bayer Hnos. S.A., Barcelona, 1999, p. 191; OCtAvio De Toledo y Ubieto, Derecho Penal, poderes públicos y negocios..., cit., p. 870 .

10 En este sentido, Casas Barquero, Observaciones técnico-juridicas sobre la incriminación del cohecho en el Código Penal español, en Documentación Jurídica No 19, 1978, p. 200.

11 Carrara, Programa de Derecho criminal. Parte especial, vol. V, traducción de José J. Ortega Torres y Jorge Guerrero, 4ª edición revisada, Ed. Temis, Bogotá, 1993, parágrafo 2545, p. 94.
} 
Oliver - Aproximación al delito de cohecho

tercer lugar, porque puede haber cohecho aún tratándose de actos por los cuales sea necesario pagar derechos.

Por otro lado, José Antón Oneca y José Arturo Rodríguez Muñoz, siguiendo a Giuseppe Maggiore, han definido al cohecho como "el hecho de aceptar el funcionario público una retribución no debida, entregada o prometida en consideración a actos de su oficio"12. Esta definición tampoco parece adecuada para la regulación que de este delito se contiene en nuestro Código Penal. En primer término, porque -al igual que la definición anterior- sólo alude al funcionario, omitiendo toda referencia al particular. Y en segundo lugar, porque el delito se configura no sólo cuando el funcionario se limita a aceptar una retribución ofrecida por el particular, sino también cuando toma la iniciativa y solicita dicho beneficio.

También Enrique Casas Barquero ha dado un concepto de cohecho, señalando que consiste en "la conducta, activa o pasiva, realizada por un funcionario público que, en virtud de una remuneración económica, tiende a incumplir sus deberes para con el Estado, así como la conducta, activa o pasiva, del particular que, mediante una retribución de carácter económico, trata de conseguir que un funcionario público quebrante el cumplimiento de los deberes que al mismo son impuestos por razón del ejercicio del cargo"13. Esta definición resulta mucho más acorde con la regulación del delito de cohecho contenida en el Código Penal. Sin embargo, no nos parece totalmente satisfactoria, toda vez que pone el acento en el incumplimiento de los deberes del cargo por parte del funcionario público, en circunstancias que, de todas las figuras típicas de cohecho contempladas en los artículos 248 y siguientes de nuestro Código Penal, en sólo una -la descrita en el artículo 248 bis- se hace alusión a la ejecución de un acto con infracción a los deberes del cargo.

Finalmente, Inmaculada Valeije Álvarez ha definido al cohecho como "un trato o pacto o un intento de llevarlo a cabo entre funcionario y particular que tiene por objeto el ejercicio de una función pública, de tal forma que la función pública en aras de ese pacto o convenio se coloca al servicio de intereses particulares que pueden entrar gravemente en colisión con los intereses públicos. La esencia del delito de cohecho es desde luego individualizable en el libre convenio al que pretenden llegar funcionario y particular, convenio que tiene por objeto la venta a cambio de un precio de las facultades jurídicas o de facto que el cargo confiere al funcionario y se concreta por este motivo en un tráfico ilícito de la función pública"14. Si bien esta definición parece bastante acertada, no creemos que permita explicar todas las situaciones que en nuestra legislación penal reciben el nombre de cohecho. Porque, por ejemplo, si un funcionario público ejecuta un acto debido propio de su cargo, en razón del cual no le están señalados derechos, cumpliendo todas las disposiciones pertinentes, y después de realizarlo solicita un beneficio económico a un particular por haberlo ejecutado, estarán satisfechas las exigencias típicas del cohecho del artículo 248 del Código Penal, a pesar de que no se podría decir que en un caso así la función pública se haya colocado al servicio de intereses particulares ni que se haya concretado un tráfico ilícito de la función pública, toda vez que ésta ya se habrá ejercido

\footnotetext{
12 Antón Oneca / Rodríguez Muñoz, Derecho Penal, Madrid, 1949, tomo II, p. 214, citado por Etcheberry, Derecho Penal. Parte Especial, tomo IV, $3^{a}$ edición, Ed. Jurídica de Chile, Santiago, 1998, p. 252.

${ }^{13}$ CASAS BARQUero, Observaciones técnico-jurídicas..., cit., p. 200.

14 Valeije Álvarez, El tratamiento penal de la corrupción del funcionario: el delito de cohecho, Ed. Edersa, Madrid, 1995, p. 47
} 
previamente conforme a los intereses públicos. En otras palabras, la definición en análisis no permite explicar las hipótesis de cohecho subsiguiente, a las que aludiremos más adelante.

También la jurisprudencia ha intentado definir al cohecho. Así, por ejemplo, el Tribunal Supremo español ha dicho que este delito consiste en "la corrupción de un funcionario realizada mediante precio y con el fin de ejecutar un hecho opuesto al cumplimiento de los deberes oficiales inherentes al ejercicio del cargo"15. Algunas de las razones esgrimidas para criticar las anteriores definiciones pueden ser reiteradas aquí, teniendo a la vista la regulación del cohecho contenida en el Código Penal. En efecto, por un lado, sólo se está haciendo alusión al funcionario, omitiendo toda referencia al particular y, por otro, se está poniendo el acento en el incumplimiento de los deberes del cargo. Pero eso no es todo. Esta definición sólo alude a la ejecución de un acto por parte del empleado público, sin hacer referencia a la omisión de un acto debido propio de su cargo.

Con todo, tras examinar la bibliografía básica existente en materia de cohecho, nos llama poderosamente la atención el hecho de que, en general, los autores se han mostrado reacios a dar un concepto unitario de este delito. Quizás la explicación esté en que la propia regulación legal del cohecho fue por años un tanto confusa ${ }^{16}$, lo cual puede haber contribuido a que los intentos doctrinales se hayan limitado a señalar los rasgos comunes a los distintos tipos penales que se engloban bajo esta denominación ${ }^{17}$.

Por nuestra parte, con el único objeto de invitar a la discusión doctrinal sobre el punto, nos atrevemos a definir el delito de cohecho como la conducta activa o pasiva de un funcionario público destinada a recibir una retribución no debida en el ejercicio de su cargo, así como la conducta activa o pasiva de un particular destinada a dar a un funcionario público una retribución no debida en el ejercicio del cargo de éste.

\footnotetext{
15 Vid. SSTS de 12 de junio de 1940, 29 de abril de 1947 y 2 de noviembre de 1962, citadas por VALEIJE ÁLVAREZ, El tratamiento penal..., cit., p. 44, nota 26.

${ }^{16}$ Cfr. la crítica en el sentido del texto, para la regulación española del delito de cohecho, de OCTAVIO DE Toledo y Ubieto, Derecho Penal, poderes públicos y negocios..., cit., p. 869.

17 Cfr. Valeije Álvarez, El tratamiento penal..., cit., pp. 43 y s., quien en defensa de los vanos intentos doctrinales señala que "aquel cometido se torna escabroso y difícil. La propia regulación legal constituye el primer escollo a superar. La generosidad y variedad con que el Código Penal describe las conductas típicas que pueden dar lugar a este delito (tanto pasivo como activo) es el primer dato que abona la confusión a la hora de establecer un concepto claro y preciso. A ello se añade la vetustez y obsolescencia de los términos empleados en su redacción, que contrasta con la claridad y sencillez con que están descritos al menos la mayor parte de los restantes tipos penales. [...] Es la propia estructura y redacción de los tipos penales del cohecho la que actúa, por así decirlo, como un telón de fondo, que impide vislumbrar cuál es la auténtica esencia del delito en estudio y, consecuentemente, cuál es la verdadera razón de su represión en el Código Penal. Prueba de ello es que [...] la doctrina hasta el momento no ha sido capaz de aportar un concepto que lo defina sencillamente y con la suficiente claridad. De ahí que se haya señalado que todos los intentos dirigidos a este fin estén, por lo general, llamados al fracaso; y que, más que definiciones, lo que pueden indicarse, a manera de conceptos generales, son aquellos escasos elementos comunes a las distintas formas típicas previstas por nuestro Código Penal vigente".
} 
Oliver - Aproximación al delito de cohecho

\section{Clasificación}

Según cuál sea el punto de vista desde el cual se le considere, el delito de cohecho admite varias clasificaciones, entre las cuales destacan las siguientes:

1.- Cohecho activo y cohecho pasivo

Ésta es, tal vez, la clasificación más usada por los autores. ${ }^{18}$ Tradicionalmente, se ha reservado la expresión cohecho activo para aludir a la conducta del particular que corrompe al funcionario público y la expresión cohecho pasivo para hacer referencia al funcionario que se deja corromper. ${ }^{19}$

La adopción de esta nomenclatura tuvo una explicación histórica. En efecto, en España, hasta antes de la reforma legal de 1944, sólo se sancionaba a título de cohecho al funcionario que recibía o aceptaba dádivas (se dejaba corromper) y al particular que las ofrecía (corrompía). ${ }^{20}$ En otras palabras, se castigaba una conducta pasiva del funcionario y una activa del particular. Así las cosas, no había ningún obstáculo para denominar cohecho pasivo al que cometía el empleado y cohecho activo al que realizaba el particular. Sin embargo, tras la mencionada reforma, se tipificó como cohecho del funcionario una conducta activa, consistente en solicitar dádivas o presentes, y como cohecho del particular una conducta pasiva, consistente en aceptar dar dádivas o presentes solicitados por el funcionario. Como se comprenderá, a partir de entonces perdió sentido la nomenclatura utilizada, toda vez que no parece correcto usar la expresión cohecho activo para aludir a una conducta pasiva de un particular, y la expresión cohecho pasivo para hacer referencia a un comportamiento activo de un funcionario. ${ }^{21}$ Lo mismo ha ocurrido en el caso de Chile. Con la modificación hecha por la ley $\mathrm{N}^{\circ} 19.645$, se tipificó como una forma de cohecho activo una conducta pasiva, consistente en que el particular consienta en dar a un empleado público un beneficio económico, y como una forma de cohecho pasivo un comportamiento activo, que consiste en que el funcionario solicite un beneficio económico o mayores derechos que los que le están señalados por razón de su cargo. Al igual que en el caso español, la terminología utilizada se ha desnaturalizado. Por eso creemos que sería más correcto hablar, simplemente, de cohecho del funcionario público $\mathrm{y}$ de cohecho del particular, distinguiendo en uno y otro caso entre comportamientos activos y pasivos. Así, habría cohecho activo del empleado público, cohecho pasivo de

\footnotetext{
18 CATAlán SENDER, Los delitos cometidos..., cit., p. 192.

19 Cfr. Labatut Glena, Derecho Penal, tomo II, $7^{\text {a }}$ edición actualizada por Julio Zenteno Vargas, Ed. Jurídica de Chile, Santiago, 2000, p. 90; ETCHeberry, Derecho Penal. Parte Especial, cit., tomo IV, p. 252.

20 Vid. Valeije Álvarez, Aspectos problemáticos del delito de concusión (diferencias con el cobecho), en Revista General de Derecho, junio 1994, pp. 6519 y s..

${ }^{21}$ Cfr. la crítica, en el sentido del texto, de Casas BARQuero, Algunos aspectos de los delitos del funcionario público y del particular relativos a dádivas, presentes, ofrecimientos o promesas, en Estudios Penales. Libro homenaje al profesor José Antón Oneca, Ed. Universidad de Salamanca, Salamanca, 1982, pp. 655 y s.; EL Mismo, Observaciones técnicojurídicas..., cit., pp. 206 y s.; RODRÍGUEZ PUERTA, El delito de cohecho: problemática jurídico-penal del soborno de funcionarios, Ed. Aranzadi, Pamplona, 1999, p. 84, nota 243; Gimeno LAHOz / Corbella Herreros, Comentarios sobre el delito de cohecho, en VV.AA., Delitos contra la Administración Pública, contra la Administración de Justicia y contra la Constitución, coordinado por C. Ganzenmüller, J. F. Escudero y J. Frigola, Ed. Bosch, Barcelona, 1998, p. 72: “...esta terminología resulta un tanto equívoca, al no tener en cuenta quién de los dos ha tomado la iniciativa corruptora".
} 
éste, cohecho activo del particular y cohecho pasivo de éste. Ésta será la terminología que emplearemos en este trabajo. ${ }^{22}$

2.- Cohecho antecedente y cohecho subsiguiente

Es ésta una clasificación que no goza de tanta fama como la anterior. Con la expresión cohecho antecedente se quiere aludir a aquella situación en la que el beneficio económico se solicita, ofrece, acepta o consiente en dar para la ejecución de un acto futuro por parte del empleado público. En cambio, la expresión cohecho subsiguiente hace referencia a los casos en que el beneficio económico se solicita, ofrece, acepta o consiente en dar como recompensa por un acto ya realizado por el funcionario. ${ }^{23}$

En la falta de una mayor difusión de este criterio de clasificación, probablemente, ha influido el hecho de que no en todos los países la regulación del delito de cohecho admite esta distinción. Es el caso, por ejemplo, de Colombia, en cuyo Código Penal no se encuentra tipificado el cohecho subsiguiente.

Algunos autores afirman que el castigo del cohecho subsiguiente no se encuentra del todo justificado desde el punto de vista de la afectación del bien jurídico, y que su punición se debe únicamente a una razón político-criminal, cual es la sospecha de un pacto previo de pago por el servicio, cuya existencia resulta difícil probar. ${ }^{24}$ Más adelante expondremos nuestra opinión sobre este punto.

En el caso de Chile, la distinción entre cohecho antecedente y subsiguiente resulta procedente, toda vez que los artículos 248 y siguientes del Código Penal, en general, se ponen tanto en la situación en que el beneficio económico solicitado, aceptado u ofrecido sea para ejecutar $u$ omitir un acto, como en la situación en que el beneficio se solicite, acepte, ofrezca o consienta en dar por haber ejecutado u omitido un acto. Sin embargo, como veremos luego, en el cohecho de funcionario público del artículo 249 sólo se tipificó una modalidad de cohecho antecedente, omitiéndose toda referencia al cohecho subsiguiente.

\section{3.- Cohecho propio y cohecho impropio}

Dentro del cohecho del funcionario público - en la terminología tradicional, cohecho pasivo-, los autores, tanto en la doctrina nacional como en la extranjera, suelen realizar una subdistinción entre el cohecho propio y el impropio. Sin embargo, creemos que el criterio que se usa para efectuar esta clasificación no es uniforme y depende de la forma en que el cohecho aparece regulado en las distintas legislaciones. En España, por ejemplo, se sostiene que el criterio para distinguir entre el cohecho propio y el impropio es

\footnotetext{
22 Tal vez por la fuerza de la costumbre y por lo arraigado que está el uso de la nomenclatura que criticamos en el texto, se ha seguido utilizando la expresión "cohecho pasivo" para aludir al que comete el funcionario público y la frase "cohecho activo" para hacer referencia al que realiza el particular, aún después de la ley $\mathrm{N}^{\circ}$ 19.645. Es el caso, por ejemplo, de Matus Acuña / Ramírez GuZmán, Lecciones de Derecho Penal Chileno. Parte Especial, Ed. Universidad de Talca, Talca, 2001, pp. 202 y ss., y de Oliver Calderón, Últimas modificaciones..., cit., pp. 39, 42, 48 y ss..

23 Cfr. Catalán Sender, Los delitos cometidos..., cit., p. 193; Casas Barquero, Algunos aspectos..., cit., p. 656; El Mismo, Observaciones técnico-jurídicas..., cit., p. 207.

${ }^{24}$ Vid. Díaz y García Conlledo, El delito de cohecho, cit., p. 167, citando a Enrique Orts Berenguer e Inmaculada Valeije Álvarez.
} 
Oliver - Aproximación al delito de cohecho

el carácter justo o injusto del acto objeto del delito. Así, sería cohecho propio aquel en el que se persigue la obtención de un acto injusto, en tanto que sería impropio aquel en el que se busca la realización de un acto justo. ${ }^{25}$ En Chile, en cambio, se afirma que el criterio que permite distinguir el cohecho propio del impropio es el carácter funcionario o de delito ministerial del acto que se quiere obtener. De este modo, el cohecho sería propio cuando lo que se busque sea la ejecución o la omisión de un acto propio del cargo del empleado público, mientras que sería impropio cuando lo que se pretenda conseguir sea la comisión de un delito funcionario. ${ }^{26}$

La señalada falta de uniformidad de criterios doctrinales para efectuar la distinción entre el cohecho propio y el impropio nos hace pensar que se trata de una clasificación que debería comenzar a ser dejada de lado. Ello debería ser así, no sólo por la poca utilidad que tiene el realizar distinciones doctrinales cuyo contenido difiere tan radicalmente, según la forma que asume la regulación de este delito en las distintas legislaciones, sino también porque la propia terminología empleada no parece adecuada. En efecto, la distinción entre cohecho propio e impropio sugiere que aquél es un verdadero cohecho y éste no. ${ }^{27}$ Algo impropio es algo que se aparta de la esencia de lo que se toma como su modelo. Tal como lo señalamos más arriba, el cohecho consiste en una conducta de un funcionario público o de un particular destinada, respectivamente, a recibir o a entregar una retribución no debida en el ejercicio del cargo de aquél. Esa es su esencia, la que no resulta alterada en nada por la naturaleza del acto que a cambio de la

${ }^{25}$ Cfr., entre otros, Rodríguez PuERTA, El delito de cohecho..., cit., p. 155.

Se afirma que en el Código Penal español de 1995 se refieren al cohecho propio del funcionario los arts. 419 , 420 y 421, en tanto que aluden al impropio los arts. 425 y 426, cuyo texto se transcribe a continuación:

Art. 419: "La autoridad o funcionario público que, en provecho propio o de un tercero, solicitare o recibiere, por sí o por persona interpuesta, dádiva o presente o aceptare ofrecimiento o promesa para realizar en el ejercicio de su cargo una acción u omisión constitutivas de delito, incurrirá en la pena de prisión de dos a seis años, multa del tanto al triplo del valor de la dádiva e inhabilitación especial para empleo o cargo público por tiempo de siete a doce años, sin perjuicio de la pena correspondiente al delito cometido en razón de la dádiva o promesa".

Art. 420: "La autoridad o funcionario público que, en provecho propio o de un tercero, solicite o reciba, por si o por persona interpuesta, dádiva o promesa por ejecutar un acto injusto relativo al ejercicio de su cargo que no constituya delito, y lo ejecute, incurrirá en la pena de prisión de uno a cuatro años e inhabilitación especial para empleo o cargo público por tiempo de seis a nueve años, $y$ de prisión de uno a dos años e inhabilitación especial para empleo o cargo público por tiempo de tres a seis años, si no llegara a ejecutarlo. En ambos casos se impondrá, además, la multa del tanto al triplo del valor de la dádiva".

Art. 421: "Cuando la dádiva solicitada, recibida o prometida tenga por objeto que la autoridad o funcionario público se abstenga de un acto que debiera practicar en el ejercicio de su cargo, las penas serán de multa del tanto al duplo del valor de la dádiva e inhabilitación especial para empleo o cargo público por tiempo de uno a tres años".

Art. 425: "1. La autoridad o funcionario público que solicitare dádiva o presente o admitiere ofrecimiento o promesa para realizar un acto propio de su cargo o como recompensa del ya realizado, incurrirá en la pena de multa del tanto al triplo del valor de la dádiva y suspensión de empleo o cargo público por tiempo de seis meses a tres años. 2. En el caso de recompensa por el acto ya realizado, si éste fuera constitutivo de delito se impondrá, además, la pena de prisión de uno a tres años, multa de seis a diez. meses e inhabilitación especial para empleo o cargo público por tiempo de diez a quince años".

Art. 426: "La autoridad o funcionario público que admitiere dádiva o regalo que le fueren ofrecidos en consideración a su función o para la consecución de un acto no probibido legalmente, incurrirá en la pena de multa de tres a seis meses".

26 Vid. Etcheberry, Derecho Penal. Parte Especial, cit., tomo IV, p. 253; Labatut Glena, Derecho Penal, cit., tomo II, p. 90; MATUs ACUÑa / RAmíREZ GuZMÁN, Lecciones..., cit., pp. 203 y s..

En nuestro Código Penal, reciben la denominación de cohecho pasivo - en nuestra terminología, cohecho del funcionario- propio las figuras de los arts. 248 y 248 bis, en tanto que se conoce con el nombre de cohecho impropio la figura del art. 249.

27 Cfr. Casas Barquero, Algunos aspectos..., cit., p. 656; El Mismo, Observaciones técnico-jurídicas..., cit., p. 207. 
indebida retribución se realiza. ${ }^{28}$ En consecuencia, mal puede llamarse cohecho impropio a lo que, sin lugar a dudas, es un delito de cohecho. Por eso, y teniendo en consideración la diferente penalidad de las figuras de cohecho del empleado público, es que en lugar de esta nomenclatura, preferimos utilizar otra que distinga entre una figura básica (la del artículo 248 del Código Penal) y dos figuras agravadas (las de los artículos 248 bis y 249 del mismo cuerpo legal) ${ }^{29}$, que será la que usaremos en este trabajo.

\section{Naturaleza unilateral o bilateral}

Durante mucho tiempo se ha discutido en la doctrina acerca de si el delito de cohecho tiene naturaleza unilateral o bilateral, es decir, respectivamente, si el cohecho del funcionario público y el cohecho del particular son dos delitos autónomos e independientes o si, por el contrario, constituyen las dos caras de un mismo y único delito. La posición que afirma que el cohecho tiene naturaleza bilateral ha señalado como argumentos principales, por un lado, el hecho de que para su perpetración se requeriría la concurrencia de dos personas -el empleado público y el particular- y, por otro, la circunstancia de que este delito consistiría en un acuerdo entre el funcionario y el particular, en cuya virtud aquél acepta de éste una compensación no debida por un acto en el ejercicio de su cargo. Por su parte, la posición que afirma que el cohecho tiene naturaleza unilateral ha argumentado a partir de la constatación de que este delito se consumaría con la mera solicitud del funcionario o el simple ofrecimiento del particular, no siendo necesario que la solicitud o el ofrecimiento sean aceptados por sus destinatarios..$^{30}$

En España esta discusión, prácticamente, no existía antes de la modificación legal que en 1944 se hizo en la regulación del delito de cohecho. En efecto, hasta antes de esta reforma la doctrina española se había uniformado en el sentido de considerar que el cohecho tenía naturaleza bilateral. ${ }^{31}$ Pero en dicho año se instauró como conducta típica en el Código Penal español la solicitud de dádivas o presentes por parte del funcionario público, porque esta forma de comportamiento, atendida la estructura bilateral que tenía el cohecho, permanecía hasta entonces impune. ${ }^{32}$ Esta modificación vino a poner en duda la tesis que afirmaba que el cohecho tenía carácter bilateral, toda vez que ya no era necesario acuerdo alguno entre el funcionario y el particular para que el delito se consumara, bastando la sola solicitud de dádiva o presente. La discusión que entonces se generó, con el correr del tiempo fue decayendo, hasta el punto que es posible afirmar que hoy en España es posición doctrinal abrumadoramente mayoritaria la que afirma la naturaleza

\footnotetext{
28 Cfr. la crítica, en el sentido indicado en el texto, de Ferreira Delgado, Delitos contra la Administración Pública, cit., p. 94.

${ }^{29}$ Cfr. la proposición, en este sentido, pero referida a la regulación española del cohecho, de RoDRíGuEZ PUERTA, El delito de cohecho..., cit., pp. 155 a 161.

30 Cfr. una exposición de estos argumentos en CASAS BARQUero, Algunos aspectos..., cit., pp. 657 y s.; EL Mismo, Observaciones técnico-jurídicas..., cit., pp. 209 y ss..

31 Vid. Rodríguez Puerta, La responsabilidad del particular en el delito de cobecho (Comentarios a la sentencia del Tribunal Supremo de 29 de abril de 1998), en Revista de Derecho y Proceso Penal, año 1999, N 1, p. 194, nota 24. 32 Cfr. Valeije Álvarez, Aspectos problemáticos..., cit., pp. 6519 y s..
} 
Oliver - Aproximación al delito de cohecho

unilateral del delito de cohecho. ${ }^{33}$ Pero existen importantes autores que, minoritariamente, defienden la naturaleza bilateral de este delito. ${ }^{34}$

En el caso de Chile, ha sido tradicional la postura que sostiene que el delito de cohecho tiene carácter bilateral. ${ }^{35}$ Sin embargo, las afirmaciones doctrinales hechas en este sentido se han formulado antes de la promulgación de la ley $\mathrm{N}^{\circ} 19.645$, en un momento en que, efectivamente, la regulación legal del cohecho presentaba una estructura bilateral. A partir de la reforma introducida por esta ley, para apreciar un delito de cohecho de funcionario dejó de ser necesario que existiera un acuerdo entre éste y un particular, bastando su sola solicitud de algún beneficio económico, aunque no fuese aceptada. Del mismo modo, para estimar concurrente un delito de cohecho de particular ya no fue imprescindible que su ofrecimiento fuera aceptado por el funcionario, bastando el solo hecho de ofrecerle un beneficio económico. En consecuencia, a nuestro juicio, es posible afirmar que el delito de cohecho, atendida su actual regulación en el Código Penal, tiene naturaleza unilateral.

\section{Bien jurídico}

La determinación del bien jurídico protegido en el delito de cohecho, si bien no es un punto muy tratado por la doctrina nacional ${ }^{36}$, ha originado una fuerte discusión en la doctrina extranjera. No sólo se ha discutido cuál es este bien jurídico, sino también si existe un único bien jurídico protegido, tanto por el cohecho del funcionario, como por el del particular, o si, por el contrario, ambas clases de cohecho buscan cautelar bienes jurídicos diferentes.

En España, dentro de quienes, minoritariamente, sostienen que el cohecho del funcionario y el cohecho del particular pretenden proteger bienes jurídicos distintos, destaca Enrique Casas Barquero. Este autor afirma que "en el delito de cohecho cometido por el funcionario el objeto de tutela está constituido por el deber básico inherente a la condición de todo funcionario público, cual es el relativo al fiel desempeño de la función del cargo [...]. De manera correlativa con el alcance del deber funcionarial, se trata de tutelar penalmente además la confianza, consustancial a la titularidad de la función, que en el titular de la misma se deposita por el Estado y por la propia sociedad en general"37. Y por lo que respecta al cohecho del particular, señala este autor que "el particular actúa en perjuicio o detrimento de las funciones públicas del Estado [...]. Su conducta implica

\footnotetext{
33 Entre quienes adhieren a esta posición mayoritaria puede verse, entre otros, a CATALÁN SENDER, Los delitos cometidos..., cit., pp. 195 y s.; Gimeno lahoz / Corbella Herreros, Comentarios..., cit., p. 72; Olaizola Nogales, El delito de cohecho, Ed. Tirant lo Blanch, Valencia, 1999, pp. 211 y ss.; Muñoz Conde, Derecho Penal. Parte Especial, 12a edición, Ed. Tirant lo Blanch, Valencia 1999, p. 957.

34 Dentro de esta posición minoritaria destacan, entre otros, RODRÍGUEZ PUERTA, La responsabilidad del particular..., cit., pp. 186 y ss.; LA MiSMA, El delito de cohecho..., cit., pp. 91 y ss.; VALEIJE ÁlvarEZ, El tratamiento penal..., cit., pp. 37 y ss., especialmente p. 42.

35 Cfr., por ejemplo, Etcheberry, Derecho Penal. Parte Especial, cit., tomo IV, p. 252; Labatut GLenA, Derecho Penal, cit., tomo II, p. 91.

36 Excepcionalmente, el profesor Gustavo Labatut Glena sí se pronuncia sobre este punto, señalando que el bien jurídico protegido en el delito de cohecho es "el decoro, el prestigio y el correcto funcionamiento de la Administración pública”. Vid. Labatut Glena, Derecho Penal, cit. tomo II, p. 90.

37 Casas Barquero, Observaciones técnico-jurídicas..., cit., pp. 213 y s..
} 
atentar no sólo contra la función concreta que incumbe al funcionario singular, sino también contra el normal desarrollo de las funciones públicas [...]. Asimismo, el comportamiento típico del cohecho realizado por el particular afecta a la esencia de la dignidad del Estado y al prestigio social que en todo momento han de ostentar los entes públicos en el marco de la ordenación jurídica de la vida social"38.

Esta posición puede ser criticada por varias razones. En primer lugar, porque eleva a la categoría de bien jurídico tutelado en el cohecho del empleado público el deber funcionarial, lo que revela una visión autoritaria que no tiene en cuenta que la existencia de la Administración Pública se explica, únicamente, por el beneficio que su actividad significa para los ciudadanos. Los deberes que emanan de los cargos públicos no se explican por sí solos, sino en cuanto su cumplimiento conduce a la prestación de un servicio para la comunidad. ${ }^{39}$ En segundo lugar, porque también considera como bien jurídico en el cohecho del funcionario la confianza que en éste depositaría el Estado y la sociedad en general. Es posible constatar que los ciudadanos, efectivamente, confían en que los funcionarios públicos se desempeñen con probidad en el ejercicio de sus cargos, pero dicha confianza no sólo se ve afectada en el cohecho, sino también en otros delitos que los empleados pueden cometer ${ }^{40}$, como, por ejemplo, en los fraudes ministeriales y en las malversaciones. No parece que esta confianza sea el bien jurídico específicamente protegido en el delito de cohecho. Además, si lo fuera, no podría apreciarse un delito de cohecho, por no resultar afectado el bien jurídico, cuando la conducta descrita en el tipo sea realizada por un funcionario que no goce de la confianza de la ciudadanía por ser, en opinión de ésta, una persona corrupta, lo cual no resultaría aceptable. En tercer lugar, porque algo parecido puede decirse respecto de la pretensión de esta posición, de considerar como bien jurídico protegido en el cohecho del particular, la dignidad del Estado y el prestigio social de los entes públicos. La existencia del Estado y de los entes públicos tiene su razón de ser en la protección del bien común, sin que se puedan justificar por sí solos. Además, la dignidad parece ser algo inherente a toda persona humana y no algo propio del Estado. Por otra parte, aún cuando un ente público no goce de prestigio en la sociedad, los particulares igualmente tienen la posibilidad de cometer un delito de cohecho cuando ofrecen a sus funcionarios beneficios económicos indebidos, lo que resultaría incompatible con una tesis que afirme que el bien jurídico tutelado en este delito es el prestigio social de los entes públicos. Y en cuarto lugar, porque esta posición plantea que es también un bien jurídico protegido en el cohecho del particular el normal desarrollo de las funciones públicas, lo cual implica sostener que el particular tendría una especie de deber de respetar el normal desempeño de las actividades de los órganos del Estado. La verdad es que no se divisa la razón para sostener que éste sea un bien jurídico que se pretende tutelar en el cohecho del particular y no en el del funcionario. La lógica indica que una afirmación correcta tendría que ser hecha en un sentido completamente inverso. Por otro lado, no hay claridad en cuanto a la fuente de la que emanaría dicho deber. Además, tal deber, en caso de existir, no podría ser elevado a la categoría de bien jurídico sino en un régimen totalitario o, al menos, autoritario.

\footnotetext{
${ }^{38}$ CASAS BARQUERO, Observaciones técnico-juridicas..., cit., p. 214.

39 Cfr. la crítica, en el sentido indicado en el texto, de Octavio de Toledo y Ubieto, La prevaricación del funcionario público, Ed. Civitas - Instituto de Criminología de la Universidad Complutense de Madrid, 1980, pp. 238 y ss. Similar, VAleije Álvarez, El tratamiento penal..., cit., pp. 27 y s..

${ }^{40}$ Cfr., en dicho sentido, la crítica de Olaizola Nogales, El delito de cohecho, cit., p. 99.
} 
Oliver - Aproximación al delito de cohecho

Mayoritariamente, la doctrina española afirma que el bien jurídico protegido es único, tanto en el cohecho del funcionario, como en el del particular. Sin embargo, la determinación de cuál es ese bien jurídico no ha sido pacífica, existiendo varias posiciones. A continuación, señalaremos y criticaremos las que nos parecen más importantes, para, enseguida, exponer nuestra postura.

1.- La confianza de los ciudadanos en el correcto funcionamiento de la Administración.

En esta postura destaca Enrique Bacigalupo, quien señala que el bien jurídico en el delito de cohecho es "la confianza pública en el ejercicio del poder administrativo o judicial según los principios del Estado de derecho"41. Esta opinión resulta criticable, por razones ya señaladas más arriba. La confianza pública en que los empleados se comporten con probidad no sólo se ve afectada en el cohecho, sino también en otros delitos funcionarios. Además, si éste fuera el bien jurídico protegido en el cohecho, no podría considerarse cometido este delito, por falta de afectación del bien jurídico, cuando la conducta sea realizada por un funcionario que no goce de la confianza pública, por ser estimada una persona corrupta.

\section{2.- El principio de imparcialidad en el ejercicio de la función pública}

Es ésta una posición que en la actualidad goza de bastante aceptación, en la que destaca, entre otros, María José Rodríguez Puerta, quien afirma que "lo que propiamente se configura como objeto de tutela es el respeto al principio de imparcialidad, que vincula de un lado a los poderes públicos, en cuanto principio alumbrador del ejercicio de la actividad administrativa y judicial, y, circunscrita a la desviación del fin, a la actividad legislativa o política. El referido principio es proyectable también a los ciudadanos, en cuanto destinatarios de esa actividad pública, dado que la relación con estos últimos viene también limitada por el respeto a la Constitución y los principios en ella consagrados" 42 . Sin embargo, también puede ser criticada. Por un lado, porque si bien es cierto que la imparcialidad efectivamente puede resultar afectada en un delito de cohecho, también lo es el hecho de que ella puede igualmente ser atacada en otros delitos funcionarios, como, por ejemplo, el tráfico de influencias. No parece, en consecuencia, que la imparcialidad sea el bien jurídico específicamente protegido en el cohecho. Y por otro lado, porque existen tipos de cohecho que no necesariamente requieren una vulneración de la imparcialidad. Es el caso, por ejemplo, del art. 248 del Código Penal. En efecto, no se aprecia cómo podría resultar afectada la imparcalidad cuando el funcionario solicita un beneficio económico para ejecutar un acto propio de su cargo que se encuentra obligado a realizar. ${ }^{43}$ Otro tanto ocurre con el art. 249 del mismo Código. Resulta difícil afirmar que sea la imparcialidad lo que se vulnere cuando el beneficio económico que el empleado pide apunta a la comisión de un delito (que no siempre será una prevaricación). ${ }^{44}$

3.- Ciertos deberes del cargo del funcionario público (lealtad, integridad, probidad, honestidad, fidelidad, etc.)

\footnotetext{
${ }^{41}$ BACigalupo, Sobre la reforma de los delitos de funcionarios, en Documentación Jurídica, año 1983, p. 1100.

${ }^{42}$ Cfr. Rodríguez PuerTA, El delito de cohecho..., cit., p. 83.

43 Vid. una argumentación similar, pero referida a los arts. 425.1 y 426 del Código Penal español, en OCTAVIO De Toledo y Ubieto, Derecho Penal, poderes públicos y negocios..., cit., p. 872.

44 Cfr. Octavio de Toledo y Ubieto, Derecho Penal, poderes públicos y negocios..., cit., p. 872, con una argumentación en el sentido del texto, pero relacionada con los arts. 419 y 425.2 del Código Penal español.
} 
Cada vez se encuentra más abandonada la postura que afirma que el bien jurídico protegido en el delito de cohecho está constituido por una serie de deberes que han sido encomendados al funcionario por el Estado y que emanarían del cargo que desempeña. Pero aún subsisten autores que la defienden. Es el caso, por ejemplo, de Carlos Granados Pérez, quien sostiene que el bien jurídico que se intenta tutelar por el cohecho es "la integridad y lealtad del funcionario al Estado, así como el cumplimiento de los deberes que al mismo le vienen impuestos por razón del ejercicio del cargo"45. Esta posición puede ser criticada por razones señaladas supra. Identificar como bien jurídico del cohecho los deberes funcionariales es propio de un sistema de tinte claramente autoritario. Los deberes de los empleados públicos no se justifican por sí solos, sino que su existencia obedece a que conducen a la prestación de un servicio para la comunidad. En otras palabras, dichos deberes no son el bien jurídico del cohecho, sino que su cumplimiento permite proteger el auténtico bien jurídico tutelado por este delito.

\section{4.- Opinión personal}

A nuestro juicio, el bien jurídico protegido en el delito de cohecho, tanto en el del funcionario público como en el del particular, es el correcto servicio que la Administración presta a los ciudadanos. ${ }^{46} \mathrm{Si}$ el cohecho consiste, según nuestra definición propuesta más arriba, en una conducta activa o pasiva de un funcionario público destinada a recibir una retribución no debida en el ejercicio de su cargo, o en una conducta activa o pasiva de un particular destinada a dar a un funcionario público una retribución no debida en el ejercicio del cargo de éste, la razón para castigar esta clase de comportamientos es que impiden o dificultan que el servicio a los ciudadanos -razón de ser de la existencia de los organismos públicos y los deberes funcionarios- se preste de manera correcta. Para que esta prestación de servicios se estime correcta, es necesario que a los ciudadanos no se les pida que paguen por ella, ni que tampoco se acepten los eventuales beneficios económicos que los ciudadanos puedan ofrecer por ella. Y en caso que la prestación de servicios no sea gratuita, para que ésta se considere adecuada, es necesario que a los particulares no se les pida que paguen más que lo que se encuentra establecido en el propio ordenamiento jurídico, ni que tampoco se acepten los eventuales beneficios económicos que puedan ofrecer por sobre el monto fijado.

Como se advertirá, esta posición nos obliga a sostener que el delito de cohecho, atendiendo al modo en que se produce la afectación del bien jurídico, puede ser de lesión o de peligro. Será un delito de lesión o daño efectivo para el bien jurídico cuando se trate del cohecho del funcionario público. Ello, porque si el empleado solicita o acepta un beneficio económico, en caso de prestaciones gratuitas, o mayores derechos que los debidos, en caso de prestaciones remuneradas, para ejecutar un acto propio de su cargo, ya habrá impedido que el servicio llamado a prestar se brinde de manera correcta. En cambio, será un delito de peligro para el mismo bien jurídico cuando se trate del cohecho del particular. Esto, porque si el particular ofrece un beneficio económico, en caso de prestaciones gratuitas, o mayores derechos que los debidos, en caso de prestaciones remuneradas, su conducta no necesariamente impedirá que el servicio se preste de manera

\footnotetext{
${ }^{45}$ Granados Pérez, El instrumento en el delito de cohecho, en VV.AA., Delitos de los funcionarios públicos, Cuadernos de Derecho Judicial, Consejo General del Poder Judicial, Madrid, 1994, p. 143.

${ }^{46}$ Seguimos en esto a OCTAVIO De Toledo y Ubieto, La prevaricación..., cit., pp. 252 y ss..
} 
Oliver - Aproximación al delito de cohecho

adecuada, toda vez que no está en sus manos, sino en las del funcionario, la efectiva lesión del bien jurídico, aunque generará un peligro de que así ocurra. ${ }^{47}$

\section{Figura básica de cohecho del funcionario público, activo o pasivo (art. 248)}

Se sanciona al empleado público que solicita (modalidad activa) o acepta (modalidad pasiva) recibir mayores derechos que los que le están señalados por razón de su cargo, o un beneficio económico para sí o un tercero para ejecutar o por haber ejecutado un acto propio de su cargo, en razón del cual no le están señalados derechos.

\section{1.- Verbo rector}

En lo que respecta al verbo rector, el tipo exige que el funcionario realice una conducta consistente en solicitar o aceptar. Lo primero significa, de conformidad con la última edición del Diccionario de la Lengua de la Real Academia Española, "pretender, pedir o buscar algo con diligencia y cuidado" ( $1^{\mathrm{a}}$ acepción); "pedir algo de manera respetuosa, o rellenando una solicitud o instancia" ( $4^{a}$ acepción). Pero no es necesario que la petición se haga en forma expresa, ya que el tipo penal no lo exige, sino que basta con que se realice de cualquier forma idónea para transmitir el mensaje. Por ejemplo, a través del simple gesto de estirar la mano. ${ }^{48}$ Lo segundo significa, conforme al mismo Diccionario, "aprobar, dar por bueno, acceder a algo" ( $2^{\mathrm{a}}$ acepción). Y al igual que la conducta de solicitar, no es necesario que la aceptación se realice de manera expresa, bastando cualquier comportamiento que revele inequívocamente la manifestación de voluntad en el sentido de consentir. Por ejemplo, guiñando un ojo o asintiendo con la cabeza. En consecuencia, no se requiere que el funcionario reciba algo del particular para que su comportamiento se considere típico, sino que basta que admita lo que el particular le ofrece. ${ }^{49}$

\section{2.- Derechos señalados por razón del cargo}

En lo que dice relación con los derechos que están señalados por razón del cargo del empleado, cabe incluir aquí todos los casos en que los funcionarios están facultados para cobrar una suma de dinero por el servicio que prestan al público. Así ocurre, por ejemplo, con los notarios, los conservadores, los archiveros y los receptores. Estos funcionarios sólo pueden cobrar los montos establecidos en sus respectivos aranceles, incurriendo en delito de cohecho si solicitan o simplemente aceptan sumas superiores.

\section{3.- Beneficio económico}

a) Campo de aplicación

\footnotetext{
${ }^{47}$ Cfr. la opinión distinta de MAtus Acuña / RAmírez GuZmán, Lecciones..., cit., p. 202, quienes califican a los delitos de cohecho como delitos de peligro, sin distinguir entre el cometido por el funcionario y el realizado por el particular.

${ }^{48}$ Cfr. CASAS BARQUero, Observaciones técnico-jurídicas..., cit., p. 216: "No es preciso que esta petición se lleve a efecto de forma expresa, sino que puede también realizarse de un modo disimulado, cuidado o encubierto, valiéndose el sujeto de cualesquiera medios comunicativos". En el mismo sentido, Olaizola Nogales, El delito de cohecho, cit., p. 231.

${ }^{49}$ Cfr. Casas Barquero, Observaciones téenico-jurídicas..., cit., p. 216.
} 
En cuanto al beneficio económico para la realización de un acto, en razón del cual no están señalados derechos al funcionario, caben aquí todas las hipótesis en las que éste no se encuentra facultado para cobrar dinero al público por el ejercicio de su cargo. Esto puede darse en dos situaciones. La primera, cuando nunca puede cobrar al público por sus servicios (por ejemplo, el forense del Servicio Médico Legal, quien no está facultado para cobrar a los familiares del difunto por realizar el examen de autopsia), y la segunda, cuando estando facultado en general para cobrar por sus servicios, en algunos casos se le prohíbe hacerlo (por ejemplo, cuando los notarios, los conservadores, los archiveros o los receptores prestan sus servicios a quien goce del privilegio de pobreza). En estos casos el funcionario no puede solicitar ni aceptar dinero alguno por la realización del acto propio de su cargo.

\section{b) Contenido}

Siempre en relación con el beneficio económico, conviene detenerse para analizar el contenido que debe tener. En la doctrina extranjera se discute acerca de la naturaleza de esta ventaja que el funcionario procura obtener o que el particular le ofrece. En España, por ejemplo, algunos autores se inclinan por sostener que el beneficio debe tener naturaleza pecuniaria ${ }^{50}$, en tanto que otros afirman que puede ser de cualquier clase, no necesariamente pecuniaria, como sería el caso, verbigracia, de la prestación de un favor de carácter sexual ${ }^{51}$. Otro tanto ocurre en Argentina. ${ }^{52}$ En Chile este tema podía ser debatido hasta la dictación de la ley $\mathrm{N}^{\circ}$ 19.645. En efecto, antes de la modificación introducida por esta ley, las disposiciones que regulaban el delito de cohecho utilizaban las palabras "dádiva" y "promesa", lo que generaba la posibilidad de discutir la naturaleza de dichas dádiva y promesa. ${ }^{33}$ Después de la promulgación de esta ley la posible discusión perdió razón de ser, porque la actual regulación del cohecho emplea la expresión "beneficio económico", lo que deja meridianamente claro que la ventaja que el empleado pretende conseguir -O que el particular le ofrece- debe ser de contenido patrimonial. Esto no quiere decir que no se sancione al funcionario que solicite un favor de naturaleza sexual a quien tenga algún asunto que dependa de la resolución de aquél. Se le castiga, pero no a título de cohecho, sino como una forma de abuso contra particulares (art. 258 del Código Penal). ${ }^{54}$ Con todo, podría discutirse si acaso es necesario que el beneficio económico se

\footnotetext{
50 Cfr., entre otros, Casas Barquero, Observaciones técnico-juridicas..., cit., pp. 229 a 233; El Mismo, Algunos aspectos..., cit., p. 662; BACIGALUPO, Sobre la reforma..., cit., pp. 1101 y s.; DÍAZ y GARCíA CONLLEDO, El delito de cobecho, cit., p. 162; CATALÁN SENDER, Los delitos cometidos..., cit., pp. 203 y s..

51 Entre otros, CóRdoBA RoDA, El cohecho de funcionarios públicos, en VV.AA., Estudios jurídicos en honor del profesor Octavio Pérez-Vitoria, tomo I, Ed. Bosch, Barcelona, 1983, pp. 177 y s.; GranAdos PÉrEZ, El instrumento..., cit., pp. 137 a 144.

52 Para una panorámica de la discusión en la doctrina argentina, puede verse BUOMPADRE, Delitos contra la Administración Pública..., cit., pp. 188 y s..

53 Cfr. Labatut Glena, Derecho Penal, cit., tomo II, p. 90, quien afirmaba que la dádiva era una liberalidad de carácter material, condición que no era indispensable en la promesa; ETCHEBERry, Derecho Penal. Parte Especial, cit., tomo IV, p. 254, quien sostenía que no era necesario que la dádiva o promesa consistiera en dinero, pero sí que fuera apreciable en dinero.

54 Pero a diferencia de lo que ocurre con el cohecho, delito en el cual no sólo se castiga la solicitud o aceptación del beneficio económico por parte del funcionario, sino también el ofrecimiento o el consentimiento en dar dicho beneficio por parte del particular, en la mencionada figura de abuso contra particulares, sólo se sanciona al empleado cuando solicita el favor sexual y no cuando lo acepta, sin que
} 
Oliver - Aproximación al delito de cohecho

traduzca en una suma de dinero. En nuestra opinión, ello no es imprescindible, bastando con que sea reducible a un valor pecuniario. Por ejemplo, la solicitud u ofrecimiento de regalar un valioso cuadro o un par de entradas en primera fila para asistir a un concierto de un internacionalmente conocido cantante de ópera, o de condonar una deuda del funcionario, cuyo acreedor es el particular, o de pagar una deuda del empleado ${ }^{55}$.

c) Cuantía y adecuación social

Resulta interesante analizar también si tiene alguna relevancia la cuantía del beneficio económico solicitado o aceptado por el funcionario público, así como el hecho de que dicho beneficio consista en atenciones que resultan corrientes en la vida social. A diferencia de la doctrina nacional, que, en lo que se nos alcanza, no se ha pronunciado sobre el punto, la doctrina extranjera sí lo ha hecho. En España, por ejemplo, en lo que dice relación con la mayor o menor cuantía del beneficio, mientras algunos sostienen que el monto de la ventaja económica resulta completamente irrelevante ${ }^{56}$, la mayoría afirma que no puede apreciarse un delito de cohecho frente a beneficios económicos de valor insignificante ${ }^{57}$. En todo caso, parte de esta postura mayoritaria matiza su aseveración, señalando que es exigible que la cuantía resulte suficiente para motivar al funcionario a actuar en el sentido que el particular desea. ${ }^{58} \mathrm{La}$ misma discusión se puede observar en la doctrina argentina.59 Por otra parte, en lo que respecta a la solicitud, aceptación, ofrecimiento o entrega de ciertos beneficios económicos en contextos socialmente adecuados o tolerados, la doctrina española afirma, en general, que en estos casos no resulta procedente apreciar un delito de cohecho. ${ }^{60}$

En nuestra opinión, a pesar de que la regulación del delito de cohecho contenida en nuestro Código Penal no hace alusión alguna a estos aspectos, las consideraciones que giran en torno a la idea de la adecuación social deben ser tomadas en cuenta. En efecto, no puede sostenerse seriamente que sea voluntad de la ley penal, expresión de soberanía popular, el castigar comportamientos que la propia sociedad tolera o estima adecuados. ${ }^{61}$

tampoco se sancione al particular que, derechamente, ofrece a aquél un servicio de carácter sexual o consiente en prestarle el favor sexual que se le ha pedido.

${ }^{55}$ El último ejemplo ha sido extraído de CATALÁn SENDER, Los delitos cometidos..., cit., p. 204.

${ }^{56}$ Entre otros, Gimeno Lahoz / Corbella Herreros, Comentarios..., cit., p. 77: "Respecto al quantum, debe destacarse que el CP 95 nada fija al respecto, por lo que es indiferente la cuantía de la dádiva o presente...”.

${ }^{57}$ Cfr., entre otros, Casas Barquero, Observaciones técnico-jurídicas..., cit., p. 243; El Mismo, Algunos aspectos..., cit., p. 664; DiAZ y GARCía CONLLEDO, El delito de cohecho, cit., p. 163.

58 Cfr., por ejemplo, Muñoz Conde, Derecho Penal. Parte Especial, cit., p. 959: "La cuantía de la dádiva o presente debe ser relevante en orden a motivar al funcionario en su actuación".

${ }^{9}$ Cfr., entre otros, Donna, Delitos contra la administración pública, Ed. Rubinzal-Culzoni, Buenos Aires, 2002, p. 219, señalando que lo relevante no es el valor de la dádiva que se ofrece o entrega al funcionario público, sino su idoneidad para motivarlo a realizar el acto; BuOMPADre, Delitos contra la Administración Pública..., cit., p. 189, afirmando que las pequeñas retribuciones no pueden descartarse del tipo penal del cohecho, toda vez que tienen un poder corruptor.

${ }^{60}$ Vid., entre otros, Catalán SEnder, Los delitos cometidos..., cit., pp. 214 y s.; Díaz y García Conlledo, El delito de cohecho, cit., pp. 165 y s.; CASAS BARQUERO, Observaciones técnico-jurídicas..., cit., pp. 243 y s.; El MiSMO, Algunos aspectos..., cit., p. 664.

${ }^{61}$ Máxime, si el art. $64 \mathrm{n}^{\circ} 5$ de la Ley 18.575, Orgánica Constitucional sobre Bases Generales de la Administración del Estado, después de señalar que contraviene el principio de probidad administrativa la conducta consistente en solicitar, hacerse prometer o aceptar, en razón del cargo o función, para sí o para 
Piénsese, por ejemplo, en los regalos que, con motivo de la celebración de Navidad, reciben ciertos funcionarios públicos por parte de los directos beneficiarios de sus servicios (carteros, basureros, etc.). Es evidente que estos regalos se hacen por haber ejecutado los actos propios del cargo del empleado en el año que termina y para que se los siga ejecutando el año siguiente (sin perjuicio de que pueda existir también una auténtica motivación solidaria), con lo cual las exigencias del tipo parecerían estar satisfechas, pero no por eso puede defenderse la procedencia del castigo de estas conductas. El criterio de la adecuación social lo impediría. ${ }^{62}$ Con todo, el análisis de la adecuación social del comportamiento debe ser realizado caso a caso, porque a pesar de que el hecho de entregar un regalo pueda, a primera vista, aparecer cubierto por este criterio, en definitiva podría resultar no estarlo (por ejemplo, cuando con ocasión de las fiestas de Navidad se regala al funcionario público no un lápiz o una agenda, sino diez millones de pesos).

En cambio, creemos que no pueden tomarse en cuenta las consideraciones que giran en torno a la idea de la insignificancia de los beneficios económicos solicitados o aceptados por los empleados públicos. Desde luego, nos estamos refiriendo a beneficios económicos solicitados o aceptados en situaciones que no se consideran socialmente adecuadas o toleradas. Cuando no pueda operar el criterio de la adecuación social, la conducta del funcionario que solicita o acepta un beneficio económico debe estimarse típica -supuesta la concurrencia de los demás elementos del tipo-, a pesar del exiguo valor que pueda tener ${ }^{63}$. Ello debe considerarse así, no sólo porque en situaciones de apremio económico un funcionario puede acceder a los requerimientos de un particular aún frente a ofrecimientos de bajísima cuantía, sino también porque así lo reclama una adecuada protección del bien jurídico. En efecto, si el bien jurídico en el delito de cohecho es, como afirmamos más arriba, el correcto servicio que la Administración presta a los ciudadanos, corrección que se traduce en la exigencia de que no se les pida que paguen por el servicio, ni que tampoco se acepten los eventuales beneficios económicos que los ciudadanos puedan ofrecer por él, o en caso de que el servicio no sea gratuito, que no se les pida que paguen más que lo que se encuentra establecido en el propio ordenamiento jurídico, ni que tampoco se acepten los eventuales beneficios económicos que puedan ofrecer por sobre el monto fijado, resultará afectado frente a cualquier beneficio económico que se pida o acepte por el empleado, aún cuando su cuantía sea muy reducida.

\section{4.- Frase “...para ejecutar o por haber ejecutado..."}

El hecho de que el artículo 248 del Código Penal se ponga, tanto en el caso en que el beneficio económico que el empleado solicita o acepta tenga por finalidad la realización futura de una acción, como en la situación en que se pretenda una recompensa por una acción ya realizada, permite sostener que resulta procedente en Chile distinguir entre el cohecho antecedente y el subsiguiente. La misma distinción es hecha en la figura

terceros, donativos, ventajas o privilegios de cualquier naturaleza, exceptúa de dicha prohibición los donativos oficiales y protocolares, y aquellos que autoriza la costumbre como manifestaciones de cortesía y buena educación. Si esto es lo que ocurre en materia administrativa, con mayor razón se debe aplicar en materia penal.

${ }^{62}$ En todo caso, esta conclusión es válida sólo para la figura básica de cohecho del empleado público que se está analizando y no para las modalidades agravadas, por las razones que más adelante se darán.

${ }^{63}$ Cfr. Carrara, Programa..., cit., volumen V, parágrafo 2554, p. 100: "No influye para nada en la esencia del delito el que el lucro [...] sea grande o pequeño, pues la justicia se ofende etiam uno nummo (aún por un solo céntimo)". 
Oliver - Aproximación al delito de cohecho

agravada de cohecho del funcionario del artículo 248 bis y en el cohecho del particular del artículo 250.

Lo primero que cabe señalar en relación con esta frase es que ella revela una importante exigencia a nivel de tipo subjetivo, cual es que debe concurrir dolo directo en el sujeto activo. En efecto, la mencionada expresión resulta incompatible con un dolo eventual. Sólo de quien obra con dolo directo puede decirse que pide o acepta algo para realizar una acción o por haberla realizado. ${ }^{64}$

El segundo comentario que merece la expresada frase es que su inclusión obliga a detenerse en el análisis de la justificación del castigo del llamado cohecho subsiguiente. Como lo señalamos más arriba, algunos autores afirman que el castigo del cohecho subsiguiente no se encuentra del todo justificado desde el punto de vista de la afectación del bien jurídico, y que su punición se debe sólo a una razón político-criminal, cual es la sospecha de un pacto previo de pago por el servicio, cuya existencia resulta de difícil probanza. ${ }^{65}$ Nuestra opinión es diferente. $\mathrm{Si}-$ como ya lo hemos señalado más de una vez- el bien jurídico protegido en el delito de cohecho es el correcto servicio que la Administración presta a los ciudadanos, lo que se traduce en la exigencia de que no se les pida que paguen por el servicio, ni que tampoco se acepten los eventuales beneficios económicos que los ciudadanos puedan ofrecer por él, o en caso de que el servicio no sea gratuito, que no se les pida que paguen más que lo que se encuentra establecido en el propio ordenamiento jurídico, ni que tampoco se acepten los eventuales beneficios económicos que puedan ofrecer por sobre el monto fijado, entonces el cohecho subsiguiente del funcionario público sí atenta contra el bien jurídico, lesionándolo. En efecto, cuando el empleado solicita o acepta de los particulares más derechos que los señalados por razón de su cargo o un beneficio económico por haber ejecutado un acto propio de su cargo en razón del cual no le están señalados derechos, no está satisfaciendo las exigencias que impone el correcto servicio que la Administración debe prestar a los ciudadanos. En consecuencia, el castigo del cohecho subsiguiente, desde el punto de vista de la afectación del bien jurídico, a nuestro juicio, se encuentra legitimado.

\section{5.- Acto propio del cargo}

Interesa también analizar qué debe entenderse por la expresión "actos propios del cargo". En la doctrina española existen dos posiciones sobre el punto. Una, que podríamos denominar restrictiva y que percibimos como minoritaria, afirma que por actos propios del cargo del funcionario público deben entenderse sólo aquellos cuya realización obecede al ejercicio de las funciones públicas, debiendo descartarse los actos que no pertenecen a la esfera de atribuciones del empleado, pero cuya comisión resulta facilitada por su condición de tal. ${ }^{66} \mathrm{La}$ otra, que podríamos calificar como amplia y que nos parece mayoritaria, sostiene que por actos propios del cargo del empleado público deben

\footnotetext{
${ }^{64}$ Cfr. Mir Puig, Los delitos contra la Administración pública en el nuevo Código penal, Ed. Bosch, Barcelona, 2000, p. 229; Octavio de Toledo y UBIETO, Derecho penal, poderes públicos y negocios..., cit., p. 876; Donna, Delitos contra la administración pública, cit., pp. 223 y s.; BuOMPADRE, Delitos contra la Administración Pública..., cit., pp. 190 y s., todos destacando la exigencia de dolo directo para tipos penales contenidos en el Código Penal español, muy similares al del artículo 248 del Código Penal chileno.

${ }^{65}$ Vid. supra, III, 2.

${ }^{66}$ Entre los partidarios de esta forma de entender la expresión "actos propios del cargo", puede verse CóRdoba RODA, El cohecho..., cit., pp. 178 y s..
} 
comprenderse aquellos que guarden relación con las actividades públicas que éste realiza, pudiendo ejecutarlos con facilidad por la función que desempeña, pero sin que sea necesario que su ejecución corresponda específicamente al ámbito de su competencia. ${ }^{67}$ En nuestra opinión, podría defenderse en España la corrección de la concepción amplia, dada la redacción de los artículos pertinentes del Código Penal de dicho país, los cuales aluden a actos relativos al ejercicio del cargo. En efecto, podría sostenerse que un acto que no sea de competencia del cargo de un funcionario, pero cuya ejecución se vea facilitada por su condición de tal, guarda alguna relación con el ejercicio de su cargo. Sin embargo, creemos que en Chile sólo la concepción restrictiva resulta defendible, atendida la regulación del cohecho contenida en nuestro Código Penal, cuyas disposiciones pertinentes aluden a actos propios del cargo. No puede sostenerse seriamente que sean actos propios del cargo de un funcionario aquellos que no pertenezcan a la competencia de éste, pero cuya realización pueda verse facilitada por su calidad de tal. Propio significa, como lo señala el Diccionario de la Lengua de la Real Academia Española, "perteneciente o relativo a alguien que tiene la facultad exclusiva de disponer de ello" (1 $1^{\mathrm{a}}$ acepción); "característico, peculiar de cada persona o cosa" ( $2^{a}$ acepción). En consecuencia, para dar un ejemplo de acto que no puede estimarse propio del cargo de un funcionario, podemos señalar que no comete esta forma de cohecho el guardia de una municipalidad que solicita o acepta un beneficio económico para destruir un expediente de sumario administrativo instruido en contra de otro empleado municipal, toda vez que este acto no se encuentra dentro de su esfera de competencia.

\section{Primera figura agravada de cohecho del funcionario público, activo o pasivo (art. 248 bis)}

Se sanciona con penas superiores a las correspondientes a la figura básica de cohecho de funcionario, al empleado público que solicita (modalidad activa) o acepta (modalidad pasiva) recibir un beneficio económico, para sí o un tercero, para omitir o por haber omitido un acto debido propio de su cargo, o para ejecutar o por haber ejecutado un acto con infracción a los deberes de su cargo (inc. $1^{\circ}$ ). Se imponen penas aún superiores si la infracción a los deberes del cargo consiste en ejercer influencia en otro empleado público, con el fin de obtener de éste una decisión que pueda generar un provecho para un tercero interesado (inc. $2^{\circ}$ ).

Con el objeto de no repetir aquí consideraciones efectuadas más arriba a propósito de la figura básica de cohecho del funcionario público, activo o pasivo, del art. 248 del Código Penal, remitimos al lector a lo que hemos señalado en relación con el verbo rector, el beneficio económico, el sentido de la frase "para ejecutar o por haber ejecutado" y el alcance de la expresión "actos propios del cargo".

Sin embargo, es necesario efectuar algunas precisiones respecto del beneficio económico. Por una parte, en la figura básica del art. 248, como ya lo señalamos, con la alusión al beneficio económico para realizar un acto en razón del cual no están señalados derechos al funcionario, se pretende cubrir las hipótesis en las que éste no se encuentra facultado para cobrar dinero al público por el ejercicio de su cargo. En cambio, la figura agravada del art. 248 bis resulta aplicable, tanto a los casos en que el empleado no se

\footnotetext{
${ }^{67}$ Cfr., dentro de esta concepción amplia, entre otros, Gimeno LaHOz / Corbella Herreros, Comentarios..., cit., p. 78; Rodríguez PuerTA, El delito de cohecho..., cit., pp. 204 y ss..
} 
Oliver - Aproximación al delito de cohecho

encuentra facultado para cobrar dinero al público por el ejercicio de su cargo, como a aquellos en que está facultado para cobrar derechos.

Por otra parte, las consideraciones que giran en torno a la idea de la adecuación social, como ya lo afirmamos, deben ser tomadas en cuenta para excluir del tipo básico del art. 248 comportamientos que, a pesar de calzar en su tenor literal, la propia sociedad tolera o estima adecuados (por ejemplo, los regalos de Navidad). En cambio, no caben consideraciones de esta clase en la figura agravada del art. 248 bis, porque lo impide la finalidad que debe tener la solicitud o aceptación del beneficio económico. Como se exige que este beneficio se solicite o acepte para omitir o por haber omitido un acto debido propio del cargo del funcionario, o para ejecutar o por haber ejecutado un acto con infracción a los deberes de su cargo, no resulta posible invocar un criterio de adecuación social para excluir conductas que quepan dentro de su tenor literal. Esto es así, porque si bien la sociedad puede considerar adecuado o tolerar, en ciertas circunstancias, que los particulares entreguen a los funcionarios beneficios porque han cumplido su deber o para que lo cumplan, no resulta aceptable para la misma sociedad que esos beneficios se entreguen porque los empleados no han cumplido su deber o para que dejen de cumplirlo.

\section{1.- Comentario a propósito de la frase "para omitir o por haber omitido"}

La conducta del funcionario que omite un acto debido propio de su cargo para obtener una ventaja parece más grave que la del empleado que pretende conseguir una ventaja a través de la ejecución de un acto debido propio de su cargo. La mayor gravedad del primer comportamiento se explica, porque en él el funcionario pretende lograr un beneficio, dejando de cumplir con sus deberes, a diferencia de lo que ocurre en el segundo, en el cual busca obtener una ventaja para cumpir con sus deberes. ${ }^{68}$ Esa es la razón por la que el legislador sanciona más severamente la primera conducta.

De la misma forma como lo señalamos al analizar la frase "para ejecutar o por haber ejecutado", contenida en el tipo básico del art. 248, la expresión "para omitir o por haber omitido" de que se vale la figura agravada del art. 248 bis implica una importante exigencia subetiva, cual es que debe concurrir dolo directo en el sujeto activo. La mencionada expresión no es compatible con un dolo eventual. Sólo de quien actúa con dolo directo se puede decir que solicita o acepta algo para omitir un acto debido o por haberlo omitido.

Un interesante problema puede plantearse si la omisión en la que se pretende que el empleado incurra, a cambio del beneficio económico, constituyera, a su vez, un delito funcionario. Creemos que en tal evento es necesario realizar una distinción. Si la omisión del acto debido constituyera un delito funcionario previsto en el párrafo 4 del título III o en el título V del libro II del Código Penal (por ejemplo, art. 149 números $4^{\circ}$ y $5^{\circ}$, art. 150 A inciso $2^{\circ}$, art. 224 número $4^{\circ}$, art. 229 , art. 237 , art. 253 , etc.), se produciría un concurso aparente de leyes penales entre el art. 248 bis y el art. 249, concurso que, por aplicación del principio de subsidiariedad, se resolvería en favor del art. 249. En esta hipótesis, en todo caso, el concurso se presentaría sólo si el empleado solicita o acepta el beneficio económico para incurrir en la omisión y no si se hace por haber incurrido en ella, porque el art. 249 únicamente alude a la solicitud o aceptación del beneficio económico para cometer alguno de los señalados delitos ministeriales y no al caso en que se lo pida o acepte por

${ }^{68}$ Cfr. Etcheberry, Derecho Penal. Parte Especial, cit., tomo IV, p. 255. 
baberlo cometido. En cambio, si la omisión del acto debido constituyera un delito funcionario distinto (por ejemplo, la omisión de los empleados públicos de presentar denuncia, de conformidad con lo previsto en los arts. 175 letras a) y b) y 177 del Código Procesal Penal), no habría ningún concurso y únicamente sería aplicable el art. 248 bis. No se realizaría el tipo penal omisivo, porque respecto de éste la conducta realizada habría alcanzado a constituir sólo un acto preparatorio impune. Cuestión distinta es determinar qué sucede cuando el funcionario no se queda en la mera solicitud o aceptación del beneficio para omitir el acto debido propio de su cargo, si la omisión constituyera otro delito ministerial, sino que va más allá y, efectivamente, incurre en la omisión. A esta hipótesis nos referiremos más adelante, cuando analicemos la figura agravada de cohecho del funcionario del art. 249.

Llama la atención el hecho de que el legislador se ponga en el caso en que el beneficio económico que se solicita o acepta por el funcionario sea para ejecutar u omitir un acto, o por haberlo ejecutado u omitido, pero no aluda al caso en que el beneficio sea para retardar un acto o por haberlo retardado. Piénsese, por ejemplo, en el hipotético caso de un fiscal que, movido por un afán de lucro, demore injustificadamente la tramitación de una orden de detención ante un juez de garantía, con el fin de permitir que la persona sospechosa de haber cometido un delito tenga la oportunidad de eludir la acción de la justicia, o bien, retarde el cumplimiento de una orden de allanamiento para darle tiempo al imputado para que retire de su domicilio los objetos que puedan comprometerle. ${ }^{69} \mathrm{~A}$ veces, conductas como éstas podrán, de todas formas, estimarse típicas, considerándolas como un caso en que el beneficio económico se solicita o acepta para ejecutar o por haber ejecutado un acto con infracción a los deberes del cargo. Ello será así, especialmente, cuando alguno de los deberes del cargo del funcionario le obligue a desenvolverse con rapidez en el ejercicio de sus funciones. Sin embargo, esto no siempre ocurrirá, sobretodo en aquellos casos en que el empleado público cuenta con un plazo máximo para realizar un acto. Por ejemplo, imagínese el caso de un funcionario, a quien se le ha encomendado la instrucción de un sumario administrativo, y que acepta un beneficio económico que le ofrece el empleado inculpado, para que demore el cierre de la investigación hasta el último día del plazo, dándole así más días para recabar antecedentes probatorios de descargo. Creemos que existe fundamento serio para sostener que casos como éstos resultan atípicos -por lo menos, en lo que dice relación con los tipos de cohecho-, por lo que denunciamos en este punto una laguna de punición. Vale la pena tener presente que en Argentina esta situación fue constatada como un vacío de punibilidad, razón por la cual fue necesario llenarlo, a través de la promulgación de una nueva ley. ${ }^{70}$

\section{2.- Frase "con infracción a los deberes de su cargo"}

Un funcionario infringe los deberes de su cargo al ejecutar un acto, cuando con su realización contraviene las disposiciones que regulan el desarrollo de las funciones propias del cargo o del servicio al que pertenece. Estas disposiciones pueden estar situadas en textos normativos tan diversos como una ley, un reglamento, un instructivo, una circular, etc..

\footnotetext{
${ }^{69}$ Estos ejemplos han sido extraídos y adaptados de DONNA, Delitos contra la administración pública, cit., pp. 221 y ss.

${ }^{70}$ Cfr. DonNA, Delitos contra la administración pública, cit., p. 221.
} 
Oliver - Aproximación al delito de cohecho

Contra lo que pudiera creerse, esta infracción de deberes del cargo del funcionario no sólo se puede presentar en el ejercicio de su actividad reglada, sino también dentro de su actividad discrecional. Particularmente, esto último puede tener lugar cuando el acto discrecional que realiza importa una desviación o un exceso del poder que se le ha conferido. $^{71}$

3.- Frase “...ejercer influencia en otro empleado público...” (art. 248 bis inciso $2^{\circ}$ )

Según lo prescrito en el inciso segundo del art. 248 bis, las penas para la figura agravada de cohecho que estamos estudiando aumentan cuando el funcionario solicita o acepta el beneficio económico para ejecutar o por haber ejecutado un acto con infracción a los deberes de su cargo, y esta infracción consiste en ejercer influencia en otro empleado con el fin de obtener de éste una decisión que pueda generar un provecho para un tercero interesado.

Se ha dicho en la doctrina nacional que se ha incorporado aquí, como forma de cometer el cohecho, el delito de tráfico de influencias del art. 240 bis del Código Penal. ${ }^{72}$ Sin embargo, no existe total coincidencia entre la modalidad de cohecho en análisis y el tráfico de influencias del art. 240 bis. Ello es así, porque mientras en el cohecho la persona favorecida con la decisión que adopte el empleado en quien el funcionario cohechado pretenda ejercer influencia, puede ser cualquiera (el particular sobornante u otra persona), en el tráfico de influencias se exige que la persona beneficiada con la decisión del empleado sólo pueda ser el funcionario que ejerce influencia en éste o alguna de las personas vinculadas con él, mencionadas en los incisos $3^{\circ}$ y $4^{\circ}$ del art. 240. De todas formas, en lo medular, la estructura es similar.

En cuanto al sentido de la expresión "ejercer influencia", creemos que para estar en presencia de esta conducta no puede bastar con una mera sugerencia o recomendación, sino que se requiere algo más. Según el Diccionario de la Lengua de la Real Academia Española, influir significa "ejercer predominio o fuerza moral" ( $2^{\mathrm{a}}$ acepción), e influencia, "poder, valimiento, autoridad de alguien para con otra u otras personas o para intervenir en un negocio" ( $2^{a}$ acepción), lo que da luz para determinar en qué consiste ese algo más. Se trata de la situación de superioridad en que debe encontrarse el funcionario público que busque influir en el empleado que tiene a su cargo la adopción de la decisión. Es decir, quien ejerce la influencia debe abusar de una situación de prevalimiento. ${ }^{73}$

\footnotetext{
${ }^{71}$ Cfr. Casas Barquero, Observaciones técnico-jurídicas..., cit., p. 228.

72 Vid. MAtus Acuña / RAmírez GuZmán, Lecciones..., cit., p. 203.

73 Seguimos en esto a OSSANDÓN WIDOW, Consideraciones político-criminales..., cit., pp. 170 y ss., quien además de afirmar que el ejercicio de la influencia debe consistir en un abuso de la función, de la relación jerárquica o de la relación personal que vincula a los dos funcionarios, sostiene que deben excluirse del tipo los supuestos en que la influencia se ejerce para obtener una decisión justa o adecuada a Derecho. Sobre el delito de tráfico de influencias, en general, puede verse también VERA VEGA, El delito de tráfico de influencias, Ed. Jurídica La Ley, Santiago, 2004.
} 
REJ - Revista de Estudios de la Justicia - No 5 - Año 2004

\section{Segunda figura agravada de cohecho del funcionario público, activo o pasivo (art. 249)}

Se castiga al empleado público que solicita (modalidad activa) o acepta (modalidad pasiva) recibir un beneficio económico, para sí o para un tercero, para cometer alguno de los delitos previstos en el título $\mathrm{V}$ o en el párrafo 4 del título III del libro segundo del Código Penal, sin perjuicio de la pena aplicable al concreto delito cometido por el funcionario.

Para no reiterar consideraciones ya hechas, nos remitimos a lo que hemos señalado más arriba a propósito del verbo rector y del beneficio económico. Pero en relación con éste y con lo dicho respecto de la adecuación social, se debe precisar que lo que cabe tener presente aquí no son los planteamientos efectuados a propósito de la figura básica de cohecho del art. 248, sino los realizados en relación con la figura agravada del art. 248 bis. Es decir, no procede acudir al principio de la adecuación social para excluir conductas que quepan dentro del tenor literal del art. 249, porque lo impide la finalidad que debe tener la solicitud o aceptación del beneficio económico. La sociedad puede considerar adecuado o tolerar, en ciertas circunstancias, que los particulares entreguen a los funcionarios beneficios porque han cumplido su deber o para que lo cumplan, pero no resulta aceptable para la misma sociedad que esos beneficios se entreguen para que los empleados cometan delitos en el ejercicio de sus cargos.

Del mismo modo, cabe recordar lo expresado a propósito de la frase "para ejecutar [...] un acto", en el sentido de la exigencia subjetiva que ella importa, pero teniendo presente lo que a continuación se indica y el hecho de que el art. 249, en vez de la señalada frase, contiene la expresión "...para cometer alguno de los crímenes o simples delitos...".

1.- Falta de tipificación del cohecho subsiguiente

El primer comentario que cabe hacer respecto de esta disposición es que llama la atención que sólo se ponga en el caso en que se solicite o acepte el beneficio económico para cometer un delito funcionario, y no en el caso en que se lo pida o acepte por haberlo cometido $^{74}$. Esto conduce al siguiente contrasentido. Para el legislador, resulta más grave la conducta de un empleado que solicita o acepta un beneficio económico por haber ejecutado un acto propio de su cargo, en razón del cual no le están señalados derechos (según el art. 248, las penas son suspensión y multa), o por haber omitido un acto debido propio de su cargo, o haber ejecutado un acto con infracción a los deberes de su cargo (según el art. 248 bis, las penas son inhabilitación, multa y una pena privativa de libertad), que el comportamiento del funcionario que solicita o acepta un beneficio económico por haber cometido un delito ministerial (conducta que resultaría impune por atípica, al no estar contemplada en el art. 249, salvo que pueda considerarse que, al haberse cometido el delito funcionario de que se trate, se ha ejecutado un acto con infracción a los deberes del cargo que el empleado detenta, siendo entonces aplicable el art. 248 bis).

2.- Pena del concreto delito ministerial cometido por el funcionario

\footnotetext{
${ }^{74}$ Cfr. la constatación de esta omisión en MATUS ACuÑa / RAMírEZ GuZMÁn, Lecciones..., cit., p. 204.
} 
Oliver - Aproximación al delito de cohecho

Con la modificación que en esta materia introdujo la ley $\mathrm{N}^{\circ} 19.645$, de 1999, para determinar la pena aplicable al empleado que cometía un delito ministerial asociado al cohecho del funcionario público agravado del art. 249, además de la pena de este último delito, pasó a ser necesario examinar la pena privativa de libertad que el inciso segundo del art. 250 establecía para el cohecho del particular asociado al cohecho del funcionario agravado del art. 248 bis, es decir, reclusión menor en grado medio. Si la pena por el concreto delito ministerial cometido por el empleado era inferior a la señalada pena privativa de libertad, el art. 249 obligaba a imponer esta última. Esta situación cambió con la ley $\mathrm{N}^{\circ}$ 19.829, de 2002, que le dio al inciso segundo del art. 249 su actual redacción. Conforme a ésta, resulta claro, sin necesidad de acudir a otra disposición a la que se remita, que la pena del empleado que comete un delito ministerial asociado a un cohecho de funcionario agravado del art. 249, sin perjuicio de la pena correspondiente a este último delito, no puede ser inferior a reclusión menor en su grado medio. No es ésta una regla que sustituya la determinación judicial concreta de la pena, sino que se trata del marco legal abstracto de pena, desde el cual el juzgador debe partir en el procedimiento de individualización de la sanción, tomando en cuenta los diversos factores que inciden en él (concursos, etapas de desarrollo del delito, intervención en el hecho, circunstancias modificatorias de responsabilidad concurrentes, extensión del mal producido por el delito, etc. $)^{75}$.

3.- Importancia de la determinación del concreto delito ministerial cometido por el funcionario público, en razón del beneficio económico solicitado o aceptado

El art. 249 sólo se pone en la hipótesis de delitos funcionarios previstos en el título V o en el párrafo 4 del título III del libro segundo del Código Penal. En tal caso se produce un concurso material de delitos, integrado por el cohecho y el respectivo delito ministerial, para el que se ha contemplado en forma especial una regla de punición en el propio texto del señalado artículo (“...sin perjuicio de la pena aplicable al delito cometido por el empleado público...”). Vale la pena, entonces, preguntarse qué sucede cuando el concreto delito ministerial cometido por el empleado es otro, como, por ejemplo, la falsificación de documento público por empleado público del art. 193 (que está en el título IV) y el atentado contra las formalidades del matrimonio del art. 388 (que está en el título VII). En estos casos, la sola solicitud o aceptación del beneficio económico por parte del funcionario no originaría todavía para éste responsabilidad penal, porque no cabría en el tipo agravado del art. 249 y, respecto del concreto delito ministerial, se trataría, en general, de un acto preparatorio impune. ${ }^{76}$ Pero si a la solicitud o aceptación del beneficio económico le sigue la efectiva comisión del delito ministerial, nacerá responsabilidad penal para el empleado por el correspondiente delito funcionario, agravada por la circunstancia modificatoria del art. 12 número 2 (cometer el delito mediante precio, recompensa o

\footnotetext{
75 Así fue señalado por el profesor Antonio Bascuñán Rodríguez en la sesión pertinente de la Comisión de Constitución, Legislación, Justicia y Reglamento del Senado, durante la tramitación del proyecto de ley que derivó en la ley $\mathrm{N}^{\circ}$ 19.829, manifestándose de acuerdo el Jefe de la División Jurídica del Ministerio de Justicia, profesor Francisco Maldonado Fuentes. Cfr. Diario de sesiones del Senado, Legislatura 347a , Ordinaria, sesión 25a, martes 3 de septiembre de 2002, pp. 2618 y s..

${ }^{76}$ Sin embargo, dependiendo del caso, podría estimarse realizado el tipo agravado del art. 248 bis, en la parte en que alude a la solicitud o aceptación de un beneficio para la ejecución de un acto con infracción a los deberes del cargo.
} 
REJ - Revista de Estudios de la Justicia - No 5 - Año 2004

promesa). ${ }^{77}$ Por último, si la solicitud o aceptación del beneficio económico tiene como finalidad la comisión de un delito ministerial contemplado fuera del título $\mathrm{V}$ y del párrafo 4 del título III, que tenga la particularidad de ser de omisión propia (por ejemplo, la omisión de los empleados públicos de presentar denuncia, de conformidad con lo previsto en los arts. 175 letras a) y b) y 177 del Código Procesal Penal) y el delito funcionario omisivo efectivamente se comete, se produciría un concurso material de delitos compuesto por el respectivo delito omisivo funcionario y el cohecho agravado del art. 248 bis del Código Penal.

\section{Figura básica de cohecho del particular, activo o pasivo (art. 250)}

Se sanciona al que ofrece (modalidad activa) o consiente en dar (modalidad pasiva) a un empleado público un beneficio económico, en provecho de éste o de un tercero, para que realice las acciones o incurra en las omisiones previstas en los artículos 248, 248 bis y 249, o por haberlas realizado o haber incurrido en ellas. ${ }^{78}$ Se castiga más severamente el ofrecer el beneficio que el consentir en darlo. ${ }^{79} \mathrm{Y}$ se establecen penas más graves para este delito cuando el beneficio que se ofrece o consiente en dar se relaciona con la comisión de delitos funcionarios del art. 249, que cuando se vincula con las acciones u omisiones del art. 248 bis, siendo la modalidad más benigna aquella en que el beneficio se refiere a las acciones del art. 248.

Para no repetir consideraciones ya efectuadas, remitimos al lector a lo que hemos señalado más arriba a propósito del beneficio económico. Pero debemos precisar, en relación con la adecuación social, que esto significa que resulta procedente acudir a este principio sólo para excluir las conductas de ofrecer o consentir en dar un beneficio económico en relación con las acciones del art. 248, a pesar de caber en el tenor literal del art. 250, y no respecto de las acciones u omisiones de los arts. 248 bis y 249. Ello es así, porque lo impide la finalidad que debe tener el ofrecimiento o el consentimiento en dar el beneficio económico. La sociedad puede estimar adecuado o tolerar, bajo ciertas circunstancias, que los particulares entreguen a los funcionarios beneficios porque han cumplido su deber o para que lo cumplan, pero no resulta aceptable para la misma

\footnotetext{
77 Salvo que, atendidas las particularidades del caso, pueda considerarse que con la sola solicitud o aceptación ya se habría realizado el tipo agravado del art. 248 bis, caso en el cual, la posterior comisión del respectivo delito funcionario daría lugar a un concurso material de delitos, compuesto por el cohecho del empleado agravado del art. 248 bis y el correspondiente delito ministerial, concurso que se sancionaría según las reglas generales.

${ }^{78}$ Nótese que en la redacción que la ley $\mathrm{N}^{\circ} 19.829$ asignó al inciso primero del art. 250 se ha incurrido en un error de sintaxis, al utilizar la expresión "o por haberla realizado". Debería sustituirse la palabra "haberla" por la voz "haberlas"

$79 \mathrm{Al}$ establecer esta forma de sancionar el cohecho del particular, introducida por la ley $\mathrm{N}^{\circ} 19.829$, se ha estimado que resulta más grave ofrecer un beneficio económico que sólo consentir en darlo al funcionario que lo ha pedido, atendido que en este último caso el particular, más bien, cede ante una presión. Así lo expusieron los abogados de la División Jurídica del Ministerio de Justicia, Sres. Francisco Maldonado Fuentes y Fernando Londoño Martínez, ante la Comisión de Constitución, Legislación y Justicia de la Cámara de Diputados, frente a una consulta del Diputado Juan Bustos Ramírez acerca de la razón de la diferencia de penalidad entre ambas situaciones. Cfr. Diario de sesiones de la Cámara de Diputados, Legislatura $347^{\mathrm{a}}$, Ordinaria, sesión $11^{\mathrm{a}}$, martes 2 de julio de 2002, p. 133. Cfr. la crítica a idéntico proceder en la regulación española del delito de cohecho, de Díaz y García CONLLEDo, El delito de cohecho, cit., p. 167.
} 
Oliver - Aproximación al delito de cohecho

sociedad que esos beneficios se entreguen para que los empleados no cumplan su deber o como recompensa por haber dejado de cumplirlo, o para que cometan delitos en el ejercicio de sus cargos.

\section{1.- Verbo rector}

Al igual que los tipos básico y agravados de cohecho del funcionario, el tipo de cohecho del particular es de conductas alternativas. Se exige que se realice un comportamiento consistente en ofrecer un beneficio económico o en consentir en darlo. Lo primero significa, según el Diccionario de la Lengua de la Real Academia Española, "comprometerse alguien a dar, hacer o decir algo" (1 $1^{\mathrm{a}}$ acepción); "presentar y dar voluntariamente algo" ( $2^{\text {a }}$ acepción). Pero no es necesario que el ofrecimiento se haga en términos formales y explícitos, porque el tipo no lo exige, sino que basta cualquier conducta que revele inequívocamente la proposición económica que el particular le hace al empleado público, como, por ejemplo, mostrarle un fajo de billetes que se tiene en el bolsillo. Lo segundo, también según el mencionado Diccionario, significa "permitir algo o condescender en que se haga" ( $1^{\mathrm{a}}$ acepción). Pero tampoco es necesario que se consienta de manera expresa en entregar al funcionario lo que éste ha pedido, bastando cualquier comportamiento que constituya una manifestación de voluntad del particular en dicho sentido, como, por ejemplo, asentir con la cabeza. Luego, no se requiere que el particular efectivamente entregue algo al empleado para que su conducta se estime típica.

\section{2.- Inclusión de la frase "...en provecho de éste o de un tercero..."}

Con la modificación introducida en esta materia por la ley $\mathrm{N}^{\circ} 19.645$, en todos los tipos de cohecho del funcionario (arts. 248, 248 bis y 249) se contempló expresamente la posibilidad de que el beneficio económico que éste solicitara o aceptara pudiese ser para sí o para un tercero. Sin embargo, nada se previó para el cohecho del particular (art. 250). La disposición que tipificaba este último delito no se ponía en el caso de beneficios económicos ofrecidos o consentidos a favor de terceros, lo que constituía un grave vacío punitivo $^{80}$. Por ejemplo, la conducta de ofrecer o consentir en dar a un partido político una importante suma de dinero, a cambio de que un funcionario público no ejerciera la labor fiscalizadora a que se encontraba obligado, quedaba fuera del tipo. Fue necesario, entonces, colmar esta laguna, lo que se hizo con la ley $\mathrm{N}^{\circ} 19.829,81$ la que agregó en el

\footnotetext{
${ }^{80}$ El Mensaje presidencial con que se inició la tramitación del proyecto de ley que derivó en la ley $\mathrm{N}^{\circ} 19.829$, en su parte pertinente, señala: "se incorpora expresamente la hipótesis de dádiva destinada a un tercero, situación que se encontraba explicitada sólo en los tipos de cohecho pasivo, omitiéndose su referencia en la figura activa". Vid. Diario de sesiones de la Cámara de Diputados, Legislatura 345a, Extraordinaria, sesión 16a , martes 13 de noviembre de 2001, p. 54. Por su parte, el Informe de la Comisión de Constitución, Legislación y Justicia de la Cámara de Diputados, recaído en el proyecto de ley, en su parte pertinente, expresa: "el tenor literal de la norma actual lleva a pensar que el beneficio ofrecido sólo puede ser en provecho del funcionario público, pero no de un tercero, razón por la que se prefirió ampliar expresamente la figura, para establecer que la dádiva puede ceder también en beneficio de un tercero". Cfr. Diario de sesiones de la Cámara de Diputados, Legislatura $347^{a}$, Ordinaria, sesión $11^{a}$, martes 2 de julio de 2002, p. 132.

${ }^{81}$ Sin embargo, en opinión del profesor Antonio Bascuñán Rodríguez, el cambio no vino a colmar ninguna laguna, porque la posibilidad de que el beneficio fuera en provecho de un tercero ya se encontraba especificada en las disposiciones que precedían al art. 250, de modo que la reforma habría venido sólo a aclarar posibles dudas, opinión con la que estuvieron de acuerdo el profesor Francisco Maldonado Fuentes y los
} 
texto del inciso primero del art. 250 la frase “...en provecho de éste o de un tercero...”. En consecuencia, hoy se castigan como cohecho del particular no sólo los casos en que el beneficio económico ofrecido o consentido por el particular vaya en provecho del funcionario, sino también aquellos en que el beneficio vaya en provecho de un tercero.

3.- Frase "para que realice las acciones o incurra en las omisiones [...] o por haberla ${ }^{82}$ realizado o haber incurrido en ellas"

Tal como lo hemos señalado para frases similares contempladas en los tipos de cohecho del funcionario, esta frase incorporada en el tipo de cohecho del particular contiene una exigencia subjetiva, cual es que debe concurrir dolo directo en el sujeto activo. En efecto, la mencionada expresión no resulta compatible con un dolo eventual. Sólo de quien actúa con dolo directo puede decirse que ofrece o consiente en dar algo para que se realicen ciertas acciones o se incurra en ciertas omisiones o por haberlas realizado o haber incurrido en ellas.

4.- Infracción al principio de proporcionalidad en el cohecho del particular asociado al cohecho de funcionario agravado del art. 249

La redacción del art. 250 permite sostener que contiene una grave infración al principio de proporcionalidad. Nos referimos a la falta de armonía que existe entre la pena aplicable al particular que ofrece o consiente en dar al empleado un beneficio económico para que cometa alguno de los delitos ministeriales señalados en el art. 249 y la pena aplicable al funcionario que solicita o acepta recibir un beneficio económico para cometer alguno de estos delitos, sin que en definitiva lo cometa. En este caso, al particular se le castigaría con penas de multa e inhabilitación (art. 250 inciso primero) y, además, con una pena privativa de libertad (art. 250 inciso tercero). En cambio, al funcionario se le sancionaría sólo con penas de multa e inhabilitación (art. 249 inciso primero); no se le impondría pena privativa de libertad, porque del inciso segundo del art. 249 se desprende que para eso sería necesario que cometa el delito ministerial que se busca con el beneficio que pide o acepta. La crítica es evidente. No resulta aceptable que el particular sea castigado con penas más graves que el funcionario público, atendida la diferente forma en que el bien jurídico resulta afectado por la conducta de cada uno. Si, como lo hemos señalado más arriba, el cohecho del funcionario es un delito de lesión o daño efectivo para el correcto servicio que la Administración debe prestar a los ciudadanos, en tanto que el cohecho del particular es un delito de peligro para el mismo bien jurídico, el respeto del principio de proporcionalidad y de lesividad debería conducir a que sea el empleado quien soporte las penas más severas y no el particular. Por eso sugerimos interpretar restrictivamente el inciso tercero del art. 250, para entender que las penas privativas de libertad allí contempladas sólo resultan aplicables cuando el funcionario efectivamente cometa el delito ministerial de que se trate. Hacemos esta sugerencia, mientras no se modifique su texto en el sentido indicado o no se cambie el art. 249, incorporando en esta disposición una pena privativa de libertad para el empleado que no llega a cometer el delito funcionario que se busca con el beneficio que solicita o acepta, corrigiendo así la denunciada falta de armonía.

miembros de la Comisión de Constitución, Legislación, Justicia y Reglamento del Senado. Cfr. Diario de sesiones del Senado, Legislatura 347a , Ordinaria, sesión 25a , martes 3 de septiembre de 2002, p. 2620.

82 Vid. nota 78. 
Oliver - Aproximación al delito de cohecho

\section{Figura privilegiada de cohecho del particular. Cohecho en causa criminal a favor del procesado (art. $250 \mathrm{bis}$ )}

Se sanciona con penas más benignas (sólo con multa) el cohecho del particular cuando tiene por objeto la realización u omisión de una actuación de las previstas en los tipos básico o agravado de cohecho del funcionario de los artículos 248 ó 248 bis, que medie en una causa criminal a favor del procesado ${ }^{83}$ y sea cometido por su cónyuge o por ciertos parientes.

\section{1.- Fundamento de la atenuación}

Poco se ha preocupado la doctrina nacional de estudiar las razones que justifican la atenuación de pena que, respecto del tipo básico de cohecho del particular del artículo 250 del Código Penal, prevé el tipo privilegiado del artículo 250 bis del mismo cuerpo legal. Pero quienes se han pronunciado sobre el punto han afirmado que el fundamento de la atenuación se encuentra en la culpabilidad, concretamente, en una menor exigibilidad de otra conducta, es decir, en que en los casos a que alude la última disposición el legislador estima menos exigible el comportamiento adecuado a Derecho, atendidos los especiales lazos que unen al autor del delito con el imputado o acusado en la causa criminal. ${ }^{84}$ Por su parte, en la doctrina española ésta parece ser la posición mayoritaria, de cara al artículo 424 del Código Penal ibérico, que consagra una atenuación de pena en términos muy similares a los del artículo 250 bis de nuestro Código Penal. ${ }^{85}$

Nuestra opinión es distinta. Por un lado, no nos parece que la presencia de algunas de las relaciones de parentesco que en la citada disposición se indican, necesariamente, conduzca a una modificación en el juicio de reproche o a una falta de normalidad motivacional del sujeto mediante normas, cualquiera sea la concepción del lector acerca de la culpabilidad. Piénsese, por ejemplo, en las relaciones de parentesco por afinidad existentes entre suegro(a) y yerno o nuera o entre cuñados. Es bastante discutible sostener que el sujeto que actúa para favorecer a personas con quienes está ligada por esta clase de relaciones lo haga siempre en una situación de anormalidad que le impida ser motivado por las normas o que a su respecto disminuya el juicio de reproche. Por otro

\footnotetext{
83 Llama la atención el hecho de que el artículo 250 bis del Código Penal aluda todavía al procesado, denominación propia del antiguo sistema de enjuiciamiento criminal. La ley $\mathrm{N}^{\circ} 19.806$, publicada en el Diario Oficial el 31 de mayo de 2002, adecuó una serie de Códigos y leyes de la República al nuevo sistema de justicia penal, modificando con dicho fin varias disposiciones del Código Penal (por ejemplo, sustituyó en los artículos 206 y 207, que aluden al delito de falso testimonio, la palabra "procesado" por la expresión "imputado o acusado"), pero olvidando actualizar el texto del citado artículo.

${ }^{84}$ Cfr. Etcheberry, Derecho Penal. Parte Especial, cit., tomo IV, p. 259, afirmando que esta disposición se inspira "...en la admisión de ciertos principios de la concepción normativa de la culpabilidad y de la no exigibilidad de otra conducta".

85 Cfr., dentro de esta posición mayoritaria, entre otros, CASAS BARQUERO, Observaciones técnico-jurídicas..., cit., p. 249; El Mismo, Algunos aspectos..., cit., p. 667; DíAz y García COnlledo, El delito de cohecho, cit., p. 168. Vid. también Olaizola Nogales, El delito de cohecho, cit., pp. 445 y ss., aludiendo a una motivación anormal fruto de la relación de afectividad y de los vínculos familiares.

Art. 424 del Código Penal español de 1995: "Cuando el soborno mediare en causa criminal a favor del reo por parte de su cónyuge u otra persona a la que se balle ligado de forma estable por análoga relación de afectividad, o de algún ascendiente, descendiente o hermano, por naturaleza, por adopción o afines en los mismos grados, se impondrá al sobornador la pena de multa de tres a seis meses".
} 
lado, el legislador no alude de modo expreso a consideraciones de afectividad u otras análogas que deban unir al sobornante con la persona favorecida con su conducta ${ }^{86}$. En consecuencia, no creemos que sean razones de menor exigibilidad del comportamiento conforme a Derecho las que explican esta atenuación de pena, sino que se trata de consideraciones de política criminal que buscan proteger la institución de la familia, atendida su importancia en nuestra sociedad, lo que nos permite afirmar que, más bien, nos encontramos en presencia de una semi excusa legal absolutoria ${ }^{87} \mathrm{o}$, si se nos permite la denominación, una excusa legal atenuatoria, que no dice relación con alguno de los elementos del delito, sino con su punibilidad.

La determinación del fundamento de esta cláusula de atenuación de pena en el cohecho del particular no es un asunto baladí. Importantes efectos se pueden derivar del hecho de sostener una u otra posición, en diversas materias. Por ejemplo, en lo que respecta al posible error acerca de la concurrencia de la relación conyugal o de parentesco. $\mathrm{Si}$ se afirma, como lo hacemos nosotros, que es ésta una semi excusa legal absolutoria, en caso de concurrir efectivamente el nexo exigido entre el autor del hecho y la persona imputada o acusada en una causa criminal, será aplicable el artículo 250 bis del Código Penal, aún cuando el sujeto activo ignore la existencia de dicho vínculo. En cambio, si se sostiene que el fundamento de la atenuación se encuentra dentro de la culpabilidad, no podrá aplicarse la citada disposición si el sujeto ignora la concurrencia del nexo parental o conyugal, siendo entonces aplicable el tipo básico de cohecho del particular del artículo 250.

\section{2.- Conducta realizada por el imputado o acusado en favor suyo}

Llama la atención el hecho de que el artículo 250 bis del Código Penal sólo aluda a los casos en que el cohecho del particular tiene lugar en causa criminal a favor del imputado o acusado, cuando éste es cónyuge o pariente de quien realiza la conducta, y no se ponga en la hipótesis en que el sobornante es el propio imputado o acusado. 88 Pareciera, en un primer acercamiento al tema, que se trata de una omisión del legislador. Sin embargo, a nuestro juicio, es esto algo lógico y coherente con la fundamentación que atribuimos a la existencia de esta cláusula de atenuación. En efecto, dado que nos encontramos en presencia de una semi excusa legal absolutoria o, en otras palabras, una excusa legal atenuatoria, fundada en consideraciones de política criminal que buscan proteger la institución de la familia, a partir del reconocimiento de su importancia en nuestra sociedad, no puede extenderse su aplicación a los casos por cuya eventual omisión nos preguntamos, porque en ellos no caben consideraciones de esta clase. Cuando el imputado o acusado realiza una conducta de cohecho en una causa criminal en favor

\footnotetext{
${ }^{86}$ Como sí lo hace el citado artículo 424 del Código Penal español. Vid. su texto en nota precedente.

${ }^{87}$ La misma discusión se plantea acerca de la determinación del fundamento de la exclusión (no atenuación) de pena en la hipótesis de encubrimiento del cónyuge o de ciertos parientes del inciso final del artículo 17 del Código Penal.

Cfr. Bajo Fernández, El parentesco en el Derecho Penal, 1973, pp. 242 y ss., quien, refiriéndose al artículo 392 del Código Penal español de 1973, precedente inmediato del artículo 424 del Código Penal español de 1995, consideraba la cláusula de atenuación allí contenida como una semi excusa absolutoria. Citado por OLAIzOLA NOGALES, El delito de cohecho, cit., p. 449.

${ }^{88}$ Cfr. la extrañeza que en la doctrina española causa idéntica omisión del artículo 424 del Código Penal español, en CaSAs Barquero, Observaciones técnico-jurídicas..., cit., p. 250; El Mismo, Algunos aspectos..., cit., p. 668; DíAZ y GarCía CONLLEDo, El delito de cohecho, cit., p. 168.
} 
Oliver - Aproximación al delito de cohecho

propio, no entran en juego dichos intereses político-criminales, por lo que no resulta pertinente la atenuación de su pena. Si el fundamento de esta cláusula, en cambio, estuviera en la disminución de la culpabilidad, por una menor exigibilidad de la conducta adecuada a Derecho -cuestión que rechazamos-, entonces sí sería procedente sostener que es ésta una omisión, porque si dicha exigibilidad disminuye cuando se quiere ayudar al cónyuge o a parientes, con mayor razón disminuirá cuando se trata de ayudarse uno mismo. ${ }^{89}$ En consecuencia, la hipótesis por la que nos cuestionamos debe ser sancionada conforme al tipo básico de cohecho del particular del artículo 250 del Código Penal.

En todo caso, lo dicho no quiere decir que al imputado o acusado que en causa criminal realiza una conducta de cohecho en favor propio nunca se le pueda atenuar la pena. Siempre será posible aplicar las reglas generales acerca de eximentes y atenuantes de responsabilidad penal fundadas en ausencia o disminución de la exigibilidad de otra conducta.

\section{Acerca del íter criminis en los diversos tipos de cohecho, tanto del funcionario, como del particular}

El cohecho es un delito de mera actividad, toda vez que se perfecciona con la realización de una conducta, sin exigirse para su consumación que se produzca un resultado material unido por relación de causalidad e imputación objetiva con el comportamiento. En consecuencia, resulta imposible concebir este delito en grado de frustración, porque si el delincuente ejecuta todos los actos que la ley pone de su cargo, el cohecho ya se habrá consumado.

Si bien en lo anterior existe claridad, ésta desaparece cuando se examina la posibilidad de concebir una tentativa de cohecho. Por un lado, hay quienes sostienen que este delito no admite formas imperfectas de ejecución ${ }^{90}$, es decir, ni frustración ni tentativa. Por otro, hay quienes señalan que es muy difícil que se dé una tentativa de cohecho. ${ }^{91}$ Finalmente, otros afirman que es perfectamente posible apreciar una tentativa de cohecho. ${ }^{92}$ Nosotros nos inclinamos por esta última postura. En efecto, consideramos procedente apreciar una tentativa en un delito de mera actividad, siempre que su ejecución sea fraccionable en el tiempo. ${ }^{93}$ Las conductas que a título de cohecho se sancionan, dependiendo de cada caso, pueden admitir fraccionamiento en el tiempo. Los comportamientos consistentes en solicitar, en el caso del cohecho del funcionario, y en ofrecer, en el caso del cohecho del particular, son susceptibles de dividirse, imaginariamente, en distintas etapas. Por ejemplo, la redacción de una carta en la que el funcionario solicita -o el particular ofrece- un beneficio económico, la entrega de la carta en las oficinas de

\footnotetext{
89 Así lo reconoce Olaizola Nogales, El delito de cohecho, cit., p. 458.

90 Cfr. Matus Acuña / Ramírez Guzmán, Lecciones..., cit., p. 203, quienes al aludir al tipo básico de cohecho del funcionario del artículo 248 del Código Penal, lo califican como un delito formal, "que no puede admitir etapas previas de desarrollo"; Gimeno LAHOZ / CORBElla Herreros, Comentarios..., cit., pp. 75 y s.; MuÑoz CONDE, Derecho Penal. Parte Especial, cit., p. 960.

91 Vid. Catalán Sender, Los delitos cometidos..., cit., p. 210; Ferreira Delgado, Delitos contra la Administración Pública, cit., p. 91.

92 Cfr. Valeije Álvarez, El tratamiento penal..., cit., pp. 239 y ss.

93 En dicho sentido, Politoff Lifschitz, Los actos preparatorios del delito. Tentativa y frustración. Estudio de dogmática penal y de Derecho penal comparado, Ed. Jurídica de Chile, Santiago, 1999, p. 20.
} 
correos, el traslado de la misma hasta el lugar de destino y su recepción por parte del destinatario. Hasta que esta última etapa no tenga lugar, no puede decirse que el empleado público haya solicitado a alguien un beneficio económico, ni que el particular se lo haya ofrecido a un funcionario, por lo que el cohecho no estará consumado, sino sólo tentado. Solicitar algo de alguien supone que el mensaje se emita y se reciba94, en tanto que ofrecer algo a alguien implica que la propuesta llegue a conocimiento del destinatario ${ }^{95}$. Imagínese, verbigracia, el caso en que para el traslado de la carta que contiene la solicitud o el ofrecimiento de un beneficio económico se recurre a un intermediario, quien, tras imponerse de su contenido, denuncia el hecho o destruye el documento. O bien, el caso en que la carta enviada se pierde en el camino. En casos como éstos, estarán satisfechas las exigencias literales del tipo de tentativa de la figura de cohecho que corresponda. En cambio, las conductas consistentes en aceptar, en el cohecho del empleado, y en consentir en dar, en el cohecho del particular, no admiten ser fraccionadas en el tiempo, por lo que respecto de ellas no sólo será imposible la frustración, sino también la tentativa.

Como se comprenderá, si se acepta la posibilidad de apreciar una tentativa de cohecho, siempre que se trate de comportamientos fraccionables en el tiempo, también será admisible el desistimiento de dicha tentativa. ${ }^{96}$ Ello ocurrirá cada vez que el sujeto abandone voluntariamente la ejecución de la conducta, evitando la consumación del delito. Por ejemplo, imagínese el caso en que un funcionario público, desde Santiago, envía una carta con una solicitud de un beneficio económico dirigida a un particular que vive en Valparaíso, a través del servicio de encomiendas de una empresa de buses y, mientras la carta es transportada a su lugar de destino, el empleado se arrepiente, viajando raudamente en dirección al puerto hasta alcanzar el bus que lleva la carta y recuperarla. Un caso como éste constituiría una tentativa desistida impune.

Una cosa es aceptar - como lo hacemos nosotros- la posibilidad de apreciar conceptualmente una tentativa de cohecho, vinculando la definición legal de la tentativa del inciso final del artículo 7 del Código Penal con el correspondiente tipo de cohecho de los artículos 248 y siguientes del mismo texto legal, y otra muy distinta es analizar si acaso la tentativa de cohecho presenta un desvalor tal que justifique su castigo. En otras palabras, si tiene un grado de lesividad suficiente para el bien jurídico que se quiere proteger con la regulación del delito de cohecho. En relación con este tema, algunos autores han señalado que la tentativa de cohecho, si bien puede conceptualmente admitirse, no puede ser sancionada, por encontrarse demasiado alejada del bien jurídico tutelado. ${ }^{97}$ Sin embargo, a nuestro juicio, el castigo de la tentativa de cohecho se encuentra plenamente justificado. Quienes se oponen a que se sancione la tentativa de cohecho, con argumentos que giran en torno a la falta de afectación suficiente del bien jurídico, lo hacen

\footnotetext{
94 Cfr. Valeije Álvarez, El tratamiento penal..., cit., p. 240. En contra, Gimeno Lahoz / Corbella Herreros, Comentarios..., cit., p. 76: “...la consumación se reputa producida en cuanto se emite la petición...”. cohecho, en el que se consideran consumadas conductas que desde los principios generales del Derecho penal suponen una tentativa (como la conducta de solicitar o la conducta de intentar corromper en el delito de cohecho activo), y que por lo tanto quedan ya bastante alejadas del bien jurídico protegido, las conductas que supongan una tentativa de éstas no tendrán el suficiente desvalor para ser castigadas en virtud del principio de fragmentariedad del Derecho penal. Quizás pudiera afirmarse que dichas conductas no suponen un ataque del bien jurídico lo suficientemente grave para ser considerado penalmente relevante".
} 
Oliver - Aproximación al delito de cohecho

a partir de concepciones del bien jurídico protegido por este delito que nosotros hemos desechado más arriba. Desde esas posiciones resulta comprensible que se propugne la impunidad de la tentativa de cohecho. Pero si se asume nuestra postura acerca del bien jurídico tutelado en el cohecho, no resulta difícil apreciar un desvalor suficiente en la tentativa de este delito para justificar su castigo. En efecto, si se acepta que el bien jurídico protegido en el cohecho es el correcto servicio que la Administración debe prestar a los ciudadanos, lo cual se traduce, entre otras cosas, en la exigencia de que a los ciudadanos no se les pida que paguen por dicha prestación o que paguen más que lo que se encuentra establecido en el ordenamiento jurídico, se podrá fácilmente colegir que la sanción de las tentativas de cohecho, cuando éstas son conceptualmente admisibles, se encuentra plenamente justificada desde el punto de vista de la afectación del bien jurídico, porque en estos casos, precisamente, se ha comenzado a pedir aquello que se quiere evitar que se pida.

\section{Bibliografía}

- BaCigaluPo, Enrique: Sobre la reforma de los delitos de funcionarios, en Documentación Jurídica, año 1983, pp. 1095-1105

- BALlÉN, Rafael: Corrupción política, Ed. Acrópolis - Ed. Jurídica Gustavo Ibáñez, Bogotá, 1994

- BuOMPadre, Jorge Eduardo: Delitos contra la Administración Pública. Doctrina y Jurisprudencia, Ed. Mave, Buenos Aires, 2001

- CARrara, Francesco: Programa de Derecho Criminal. Parte Especial, volumen V, traducción de José J. Ortega Torres y Jorge Guerrero, $4^{a}$ edición revisada, Ed. Temis, Bogotá, 1993

- CASAS BARQUero, Enrique: Observaciones técnico-jurídicas sobre la incriminación del cohecho en el Código Penal español, en Documentación Jurídica N 19, 1978, pp. 197-263

- Algunos aspectos de los delitos del funcionario público y del particular relativos a dádivas, presentes, ofrecimientos o promesas, en Estudios Penales. Libro homenaje al profesor José Antón Oneca, Ed. Universidad de Salamanca, Salamanca, 1982, pp. 655-671

- CATALÁN SENDER, Jesús: Los delitos cometidos por autoridades y funcionarios públicos en el nuevo Código Penal (doctrina y jurisprudencia), Ed. Bayer Hnos. S.A., Barcelona, 1999

- CÓRDOBA RODA, Juan: El cohecho de funcionarios públicos, en VV.AA., Estudios jurídicos en honor del profesor Octavio Pérez-Vitoria, tomo I, Ed. Bosch, Barcelona, 1983, pp. 175-190

- DíAz y García CONLLEDO, Miguel: El delito de cohecho, en VV.AA., Delitos contra la Administración Pública, edición al cuidado de Adela Asúa Batarrita, Instituto Vasco de Administración Pública, Bilbao, 1997

- DONNA, Edgardo Alberto: Delitos contra la administración pública, Ed. Rubinzal-Culzoni, Buenos Aires, 2002

- Etcheberry, Alfredo: Derecho Penal. Parte Especial, tomo IV, $3^{a}$ edición, Ed. Jurídica de Chile, Santiago, 1998

- Ferreira Delgado, Francisco J.: Delitos contra la Administración Pública, $2^{\mathrm{a}}$ edición, Ed. Temis, Bogotá, 1985

- Gimeno LahOz, Ramón / Corbella Herreros, Teresa: Comentarios sobre el delito de cohecho, en VV.AA., Delitos contra la Administración Pública, contra la Administración de Justicia y contra la Constitución, coordinado por C. Ganzenmüller, J. F. Escudero y J. Frigola, Ed. Bosch, Barcelona, 1998, pp. 71-88 
REJ - Revista de Estudios de la Justicia - No 5 - Año 2004

- Granados PÉrez, Carlos: El instrumento en el delito de cohecho, en VV.AA., Delitos de los funcionarios públicos, Cuadernos de Derecho Judicial, Consejo General del Poder Judicial, Madrid, 1994, pp. 129-152

- Labatut Glena, Gustavo: Derecho Penal, tomo II, $7^{\text {a }}$ edición actualizada por Julio Zenteno Vargas, Ed. Jurídica de Chile, Santiago, 2000

- Matus Acuña, Jean Pierre / Ramírez Guzmán, María Cecilia: Lecciones de Derecho Penal Chileno. Parte Especial, $1^{\text {a }}$ edición, Ed. Universidad de Talca, Talca, 2001

- Mir Puig, Carlos: Los delitos contra la Administración pública en el nuevo Código penal, Ed. Bosch, Barcelona, 2000

- Muñoz Conde, Francisco: Derecho Penal. Parte Especial, Ed. Tirant lo Blanch, 12a edición, Valencia, 1999

- Octavio de Toledo y UBieto, Emilio: Derecho Penal, poderes públicos y negocios (con especial referencia a los delitos de cohecho), en VV.AA., El nuevo Código Penal: propósitos y fundamentos, Libro Homenaje al profesor Dr. Ángel Torío López, Ed. Comares, Granada, 1999, pp. 861-878

- La prevaricación del funcionario público, Ed. Civitas - Instituto de Criminología de la Universidad Complutense de Madrid, 1980

- Olaizola Nogales, Inés: El delito de cohecho, Ed. Tirant lo Blanch, Valencia, 1999

- Oliver Calderón, Guillermo: Últimas modificaciones en la regulación del delito de cohecho (ley $N^{\circ}$ 19.829), en Revista Chilena de Derecho, volumen 30, $\mathrm{N}^{\circ} 1$, año 2003, Sección Estudios, pp. 39-53

- OSSANDÓN WidOW, María Magdalena: Consideraciones político-criminales sobre el delito de tráfico de influencias, en Revista de Derecho de la Universidad Católica del Norte $\mathrm{N}^{\circ} 10$, año 2003, pp. 161-180

- Politoff Lifschitz, Sergio, Los actos preparatorios del delito. Tentativa y frustración. Estudio de dogmática penal y de Derecho penal comparado, Ed. Jurídica de Chile, Santiago, 1999

- Rodríguez PuERTA, María José: El delito de cohecho: problemática jurídico-penal del soborno de funcionarios, Ed. Aranzadi, Pamplona, 1999

- La responsabilidad del particular en el delito de cohecho (Comentarios a la sentencia del Tribunal Supremo de 29 de abril de 1998), en Revista de Derecho y Proceso Penal, año 1999, N 1, pp. 183-207

- Rodríguez RAmOS, Luis: Transfuguismo retribuido y cohecho, en Actualidad Penal 19941, pp. 439-448

- SABÁN GODOY, Alfonso: El marco jurídico de la corrupción, Ed. Civitas, Madrid, 1991

- VALEIJE ÁlvarEZ, Inmaculada: El tratamiento penal de la corrupción del funcionario: el delito de cohecho, Ed. Edersa, Madrid, 1995

- Aspectos problemáticos del delito de concusión (diferencias con el cobecho), en Revista General de Derecho, junio 1994, pp. 6517-6542

- Vera VegA, Jaime Andrés: El delito de tráfico de influencias, Ed. Jurídica La Ley, Santiago, 2004 